\title{
Lifestyle and Pain following Cancer: State-of-the-Art and Future Directions
}

\author{
Astrid Lahousse $1,2,3,4, * \mathbb{D}$, Eva Roose ${ }^{2,3,4}$ (D) , Laurence Leysen ${ }^{1,2,3,4}$, Sevilay Tümkaya Yilmaz ${ }^{2,3}$, \\ Kenza Mostaqim ${ }^{2,3,4}$, Felipe Reis ${ }^{3,5,6}$, Emma Rheel ${ }^{2,3,7}$, David Beckwée ${ }^{2,4}$ (D) and Jo Nijs ${ }^{2,3,8,9}$
}

Citation: Lahousse, A.; Roose, E.; Leysen, L.; Yilmaz, S.T.; Mostaqim, K.; Reis, F.; Rheel, E.; Beckwée, D.; Nijs, J. Lifestyle and Pain following Cancer: State-of-the-Art and Future Directions. J. Clin. Med. 2022, 11, 195. https://doi.org/10.3390/ jcm11010195

Academic Editor: Giustino Varrassi

Received: 30 November 2021

Accepted: 23 December 2021

Published: 30 December 2021

Publisher's Note: MDPI stays neutral with regard to jurisdictional claims in published maps and institutional affiliations.

Copyright: (c) 2021 by the authors. Licensee MDPI, Basel, Switzerland. This article is an open access article distributed under the terms and conditions of the Creative Commons Attribution (CC BY) license (https:// creativecommons.org/licenses/by/ $4.0 /)$.
1 Research Foundation-Flanders (FWO), 1000 Brussels, Belgium; Laurence.leysen@vub.be

2 Department of Physiotherapy, Human Physiology and Anatomy, Faculty of Physical Education and Physiotherapy (KIMA), Vrije Universiteit Brussel, 1090 Brussels, Belgium;

Eva.Charlotte.S.Roose@vub.be (E.R.); sevilay.tumkaya.yilmaz@vub.be (S.T.Y.);

kenza.mostaqim@vub.be (K.M.); Emma.Rheel@vub.be (E.R.); David.Beckwee@vub.be (D.B.); jo.nijs@vub.be (J.N.)

3 Pain in Motion Research Group (PAIN), Department of Physiotherapy, Human Physiology and Anatomy, Faculty of Physical Education and Physiotherapy (KIMA), Vrije Universiteit Brussel, 1090 Brussels, Belgium; felipe.reis@ifrj.edu.br

4 Rehabilitation Research (RERE) Research Group, Department of Physiotherapy, Human Physiology and Anatomy, Faculty of Physical Education and Physiotherapy (KIMA), Vrije Universiteit Brussel, 1090 Brussels, Belgium

5 Physical Therapy Department, Instituto Federal do Rio de Janeiro (IFRJ), Rio de Janeiro 20270-021, Brazil

6 Postgraduation Program, Clinical Medicine Department of Universidade Federal do Rio de Janeiro (UFRJ), Rio de Janeiro 21941-901, Brazil

7 Department of Experimental-Clinical and Health Psychology, Ghent University, 9000 Gent, Belgium

8 Department of Physical Medicine and Physiotherapy, University Hospital Brussels, 1090 Brussels, Belgium

9 Unit of Physiotherapy, Department of Health and Rehabilitation, Institute of Neuroscience and Physiology, University of Gothenburg, 40530 Gothenburg, Sweden

* Correspondence: astrid.lucie.lahousse@vub.be; Tel.: +32-(0)-247-745-27

\begin{abstract}
This review discusses chronic pain, multiple modifiable lifestyle factors, such as stress, insomnia, diet, obesity, smoking, alcohol consumption and physical activity, and the relationship between these lifestyle factors and pain after cancer. Chronic pain is known to be a common consequence of cancer treatments, which considerably impacts cancer survivors' quality of life when it remains untreated. Improvements in lifestyle behaviour are known to reduce mortality, comorbid conditions (i.e., cardiovascular diseases, other cancer, and recurrence) and cancer-related side-effects (i.e., fatigue and psychological issues). An inadequate stress response plays an important role in dysregulating the body's autonomic, endocrine, and immune responses, creating a problematic back loop with pain. Next, given the high vulnerability of cancer survivors to insomnia, addressing and treating those sleep problems should be another target in pain management due to its capacity to increase hyperalgesia. Furthermore, adherence to a healthy diet holds great anti-inflammatory potential for relieving pain after cancer. Additionally, a healthy diet might go hand in hand with weight reduction in the case of obesity. Consuming alcohol and smoking have an acute analgesic effect in the short-term, with evidence lacking in the long-term. However, this acute effect is outweighed by other harms on cancer survivors' general health. Last, informing patients about the benefits of an active lifestyle and reducing a sedentary lifestyle after cancer treatment must be emphasised when considering the proven benefits of physical activity in this population. A multimodal approach addressing all relevant lifestyle factors together seems appropriate for managing comorbid conditions, side-effects, and chronic pain after cancer. Further research is needed to evaluate whether modifiable lifestyle factors have a beneficial influence on chronic pain among cancer survivors.
\end{abstract}

Keywords: cancer survivor; chronic pain; lifestyle; diet; obesity; physical activity; stress; sleep 


\section{Introduction}

Cancer has overtaken vascular diseases as the leading cause of death in high-income countries [1]. On top of that, it is expected that the global cancer burden will grow $47 \%$ by 2040 [2]. Despite these appalling numbers, cancer survivorship has fortunately increased to $70 \%$ in developed countries, mainly due to early detections and treatment advances [3].

Different definitions for cancer survivor (CS) exist, but according to a systematic review of Marzorati et al., (2017), the most widely used definition is: "being a CS, starts on the day of diagnosis and continues until the end of life" [4]. Three cancer survivorship phases can be distinguished: "acute survivorship" (i.e., early-stage or time during curative treatment), "permanent survivorship" (i.e., living with cancer or also called the palliative stage), and "extended survivorship" (i.e., cured but not free of suffering) [4]. This article focuses on the extended survivorship phase since it is difficult for cancer survivors (CSs) to recognize themselves as 'cured' if they continue to suffer after treatment completion [4]. Unfortunately, in this phase, an important proportion of these CSs will face unwanted and debilitating adverse effects that arise or persist beyond primary treatment, which is frightening and should therefore be dealt with seriously [5].

Chronic pain is one of these and occurs in $40 \%$ of CSs [6]. Chronic pain is defined by the International Association for the Study of Pain (IASP) as pain that persists or recurs for longer than three months [7]. Unrelieved pain can have considerable adverse consequences on a CSs' quality of life [6]. Therefore, providing CSs with optimal pain treatments is essential to reduce their psychological, physical, and socio-economic impact [6]. Although several initiatives attempted to increase awareness about (post) cancer pain (e.g., the Global Year Against Cancer Pain in 2008 promoted by IASP), chronic pain in CSs remains undertreated, misunderstood, and highly prevalent [6].

Nowadays, the National Comprehensive Cancer Network guidelines [8] advise pharmacological and non-pharmacological treatments for pain during cancer treatment, but after treatment, a decrease of pain medication is recommended to avoid the risk of addiction, misuse, and adverse effects such as opioid-induced hyperalgesia and sleeping disruptions. Unfortunately, shifting towards non-pharmacological treatments remains challenging for many oncologists since they are used to treat patients with acute pain associated with cancer or its therapy [9]. However, the aggressive and curative treatments, including surgery, chemo-, radio- and or maintenance therapy, are not the only factors contributing to the transition of acute to chronic pain. Other factors such as young age at diagnosis, depression, anxiety, low education, and negative lifestyle behaviour (e.g., high body mass index (BMI), low physical activity levels, high alcohol consumption, etc.) might have an impact as well [10-12]. Unfortunately, not all these factors are treatable or modifiable. However, new evidence on healthy lifestyle behaviour demonstrates promising results on pain, quality of life, cancer recurrence, psychological well-being [13-16]. A healthy lifestyle is defined as actions or method one initiate to achieve optimum health and lower the risk of disease or early death [17], which underlines the need to target (pain) multimodally and tailor treatment according to the CS's needs [18]. Therefore, the purpose of this paper is to review and update knowledge on chronic pain and modifiable lifestyle factors in CSs and to discuss the beneficial impact of modifiable lifestyle factors on chronic pain after cancer (Figure 1). 


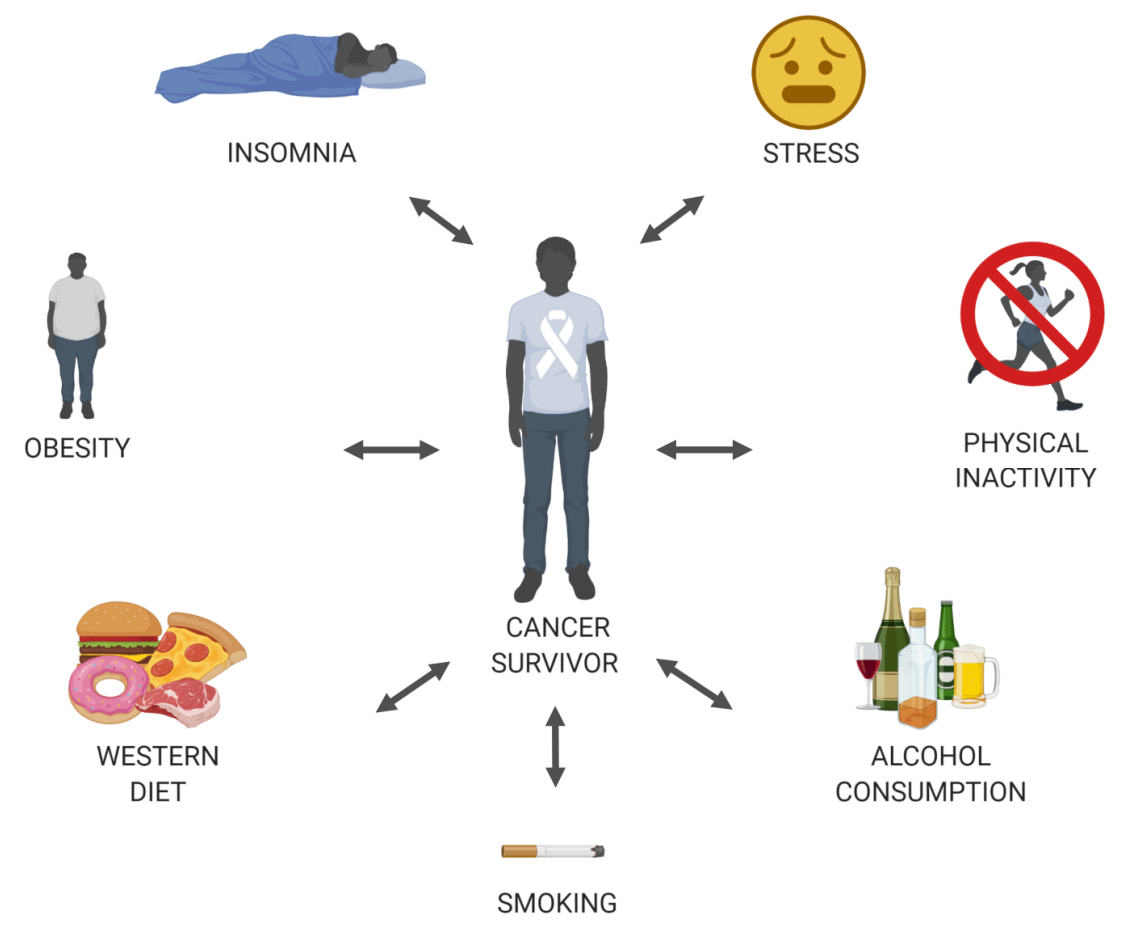

Figure 1. Discussed modifiable lifestyle factors in cancer survivors and might contribute to chronic pain after cancer (Creates with BioRender.com (accessed on: 26 November 2021)).

\section{Methods}

The best evidence regarding lifestyle behaviour and chronic pain in CSs was retrieved in PubMed and Web of Science up to September 2021. Relevant articles were selected by combining the following keywords: CS, chronic pain, lifestyle factors, risk factors, smoking, dietary intake, physical activity, obesity, medication, distress, stress, sleep disorders. To be included, articles had to meet the following criteria: (1) display original data in CSs; (2) address the aims of this review; (3) be published as full articles; and (4) written in English, Dutch, German or French. The following criteria were applied for exclusion: (1) articles reporting animal studies; and (2) studies with the following study design: case reports, congress proceedings, abstracts, letters to the editor, opinions or editorials.

\section{State-of-the-Art}

\subsection{Pain}

Chronic cancer-related pain represented in the International Classification of Diseases (ICD-11) differs from the pain of other chronic pain populations [19]. Chronic pain in CSs is caused by damage of primary cancer, its metastasis or its treatment, inducing chronic secondary pain syndromes such as musculoskeletal and neuropathic pains [7]. That can persist over time if no adequate pain management was provided initially [7].

Glare et al., (2014) published a comprehensive overview of the types of treatmentrelated cancer pain arising after the curative treatments [19]. For example, post-operative syndromes might occur after surgery, such as phantom pain after amputation, post-mastectomy pain and other complications [19]. Furthermore, chemo- and radiotherapy can also cause adverse effects. Chemotherapy, for example, can cause symmetrical painful numbness, burning, and tingling in both hands and feet. On top of that, it could also lead to osteoporosis, osteonecrosis, arthralgias, and myalgia. Radiotherapy can lead to serious adverse effects caused by ionising radiation, inducing reactive oxygen species (ROS) production, and DNA and regulatory proteins damage to targeted cells. These provoke apoptosis and increased inflammation in the exposed cells and the neighbouring cells by radiation-induced bystander effects, possibly leading to plexopathies and osteoradionecrosis $[19,20]$. Maintenance therapy like aromatase inhibitors can produce arthralgia and myalgia [19]. In addition to these 
adverse effects, health care providers have to evaluate new arising or aggravating pain complaints with caution because these can indicate a recurrence or a second malignant tumour [19].

Despite the existing guidelines, chronic pain remains underrecognized and mistreated in the extended survivorship phase [5]. Under recognition might be due to: (1) patients' belief that pain is inevitable and uncontrollable, causing them not to report pain to their physicians; and/or (2) physicians' poor knowledge of pain assessment methods [21]. Mistreatment of pain, on the other hand, might be due to: (1) suboptimal communication between CSs and physicians; (2) non-adherence of the patients due to misconception of pain medication; and/or (3) lack of knowledge or confidence of the physicians in applying pain management guidelines in the clinical field [22]. Moreover, CSs typically are insufficiently informed about the origin of their pain, the possibilities of pain relief, and how they can access support when needed, which might affect their happiness of having survived and beaten cancer [23-25].

Over the last decade, the education provided to CSs made a shift from a biomedical pain management, falling short in explaining persistent pain, to a biopsychosocial pain management [26]. This is in concordance with recent findings of the multidimensional aspect of pain [23]. Psychosocial factors, such as cognitive appraisals and expectations, are cornerstones in the patient's pain experience and might bring patients in a downward spiral if not considered [27]. The underlying mechanism can be explained by the fact that psychological factors and pain sensations share similar brain activity, such as the prefrontal cortex, thalamus, hypothalamus, and amygdala and might subsequently affect the descending nociceptive pathways of the periaqueductal grey and rostro-ventral medulla [28]. So, depressive mood, anxiety, and cognitions play an essential role in pain modulation, and the understanding of its mechanism is primordial for appropriate assessment and treatment $[10,28]$. One cognitive appraisal that gained attention in the past years is perceived injustice (PI) [29,30]. It is demonstrated that people experiencing PI, attribute blame to others for their suffering, have the tendency to interpret their losses as severe and irreparable, and experience a sense of unfairness [29] (e.g., someone who never smoked yet was diagnosed with lung cancer). A systematic review showed significant associations between PI and worse pain-related outcomes, including more intense pain, more disability, and worse mental health [31]. These along with lower quality of life are seen in breast CSs with higher PI scores, and PI rather than pain catastrophizing mediates the relationship between pain and quality of life [32]. A more intense expression in terms of their suffering and loss is seen due to increased maladaptive pain behaviour. In turn, this increases the likelihood of being prescribed opioids [29,33]. People displaying more maladaptive pain behaviour affect clinicians' decision to prescribe opioids [34]. Considering the known long-term adverse effects of long-term opioid use [9] and the possibility of developing opiate-induced hyperalgesia [35], PI seems to be a new perspective that should be further investigated in the future.

Other factors that also play a vital role in chronic pain after cancer are associated with patients' healthy lifestyle behaviour. Addressing modifiable lifestyle factors is essential to prevent recurrence of cancer, adverse effects, mortality, as well as improving quality of life and pain relief $[36,37]$. These factors' impacts and their relationship with pain in CSs are discussed in detail in the following sections of this paper (Figure 2). 


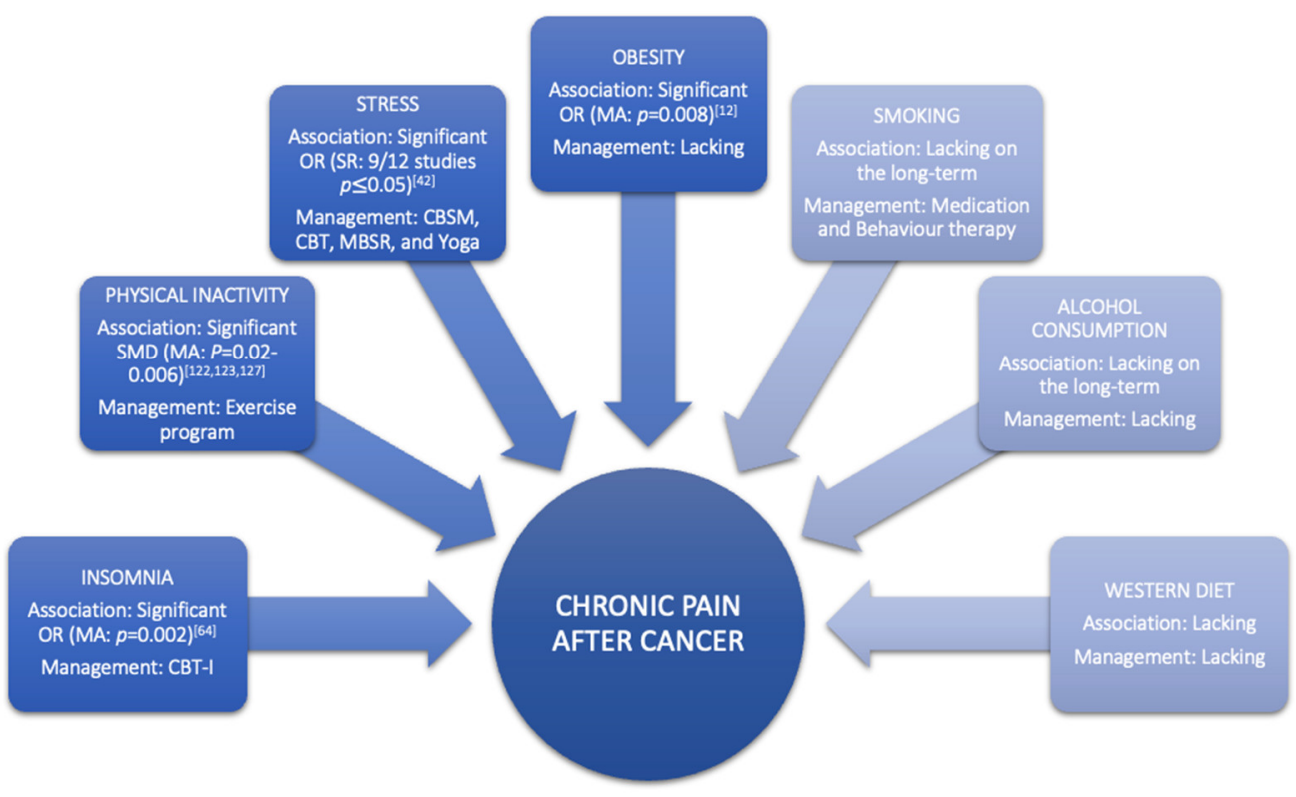

Figure 2. Evidence of modifiable lifestyle factors contributing to chronic pain in cancer survivors. Abbreviations: CBT(-I): Cognitive behavioural therapy (Insomnia); CBSM: Cognitive Behavioural Stress Management; MA: Meta-analysis; MBSR: Mindfulness-based Stress Reduction; OR: Odds Ratio.

\subsection{Lifestyle Behaviour}

\subsubsection{Stress}

Stress has been categorised as "the health epidemic of the 21st century" by the World Health Organization (WHO) [38]. It has been defined as a state, whether an actual or perceived event disturbs the physiological homeostasis or the psychological well-being [39,40]. About $12.6 \%$ of CSs will develop a lifetime cancer-related post-traumatic stress disorder [41]. Additionally, during survivorship, a substantial proportion of CSs are confronting lingering adverse events and/or experiencing an intense fear of recurrence, both causing anxiety and major distress [42]. Cancer-related distress is defined as a state during which CS cannot deal with their cancer, treatment, or adverse effects due to interference of a multifactorial unpleasant psychological, social, spiritual, or physical event. Distress can transfer normal feelings to disabling problems such as panic attacks, depression, anxiety, existential crises [43]. The presence of chronic stress or distress sustains the overproduction of pro-inflammatory cytokines, which in turn induces fatigue, sleep disorders, depression, and symptoms of sickness [44]. The other stress-related mechanisms behind a heightened inflammation level are higher stress-induced sympathetic activity or a dysregulated hypothalamic-pituitary-adrenal axis (and associated cortisol dysbalance as a characteristic feature of long-term stress exposure) [44,45]. New insights also point out that distress in CSs changes the function and/or structure of some areas of the brain, such as the thalamus, amygdala, prefrontal cortex, hippocampus, subgenual area, hypothalamus, basal ganglia and insula, which are mainly the same areas associated with chronic pain $[28,46]$. Understanding these changes may open new treatment perspectives and enhance the quality of provided interventions for distress among CSs.

Early screening of distress might enhance treatment response [42,47]. As stated in the systematic review of Syrowatka et al., (2017), several predictors for distress after cancer could be identified according to the provided treatment, sociodemographic characteristics, comorbidities, and modifiable lifestyle factors (Table 1, Figure 2) [42]. Interestingly, pain is one of the manageable risk factors for distress creating a problematic back loop because distress, in turn, promotes pain by dysregulating the autonomic, endocrine, and immune response $[44,48]$. This vicious cycle can be interrupted by cognitive behavioural stress management (CBSM) consisting of aspects of cognitive behavioural therapy (CBT) [49-51] or, more precisely, coping skills for stress management combined with relaxation train- 
ing [45,52-54]. According to recent published systematic reviews and meta-analyses, CBT has a beneficial effect on cortisol secretion, distress, anxiety, depression, emotional wellbeing, and negative thoughts in CSs [49-51]. Mindfulness-based stress reduction (MBSR) and yoga have also shown promising results on distress in CSs (Figure 2) [52-54].

\subsubsection{Sleep}

Insomnia is one the most frequently experienced survivorship concerns and is characterised by difficulty with sleep initiation, duration, consolidation, and quality, resulting in daytime impairments and distress. These difficulties have to occur at least three times a week for more than one month [55]. Insomnia affects more than $30 \%$ of CSs years after treatment ending [56-58]. The two-fold higher prevalence rate in comparison to the general population can be attributed to the emotional consequences of cancer diagnosis, the direct effects of cancer treatment, and its side-effects [56]. Among cancer patients, prevalence numbers of insomnia are the highest in breast and gynaecologic cancers compared to prostate cancer [56]. Breast CSs are particularly vulnerable to insomnia due to fear of recurrence, endocrine therapy, and other hormonal changes related to breast cancer treatment [59-61]. Due to hormonal changes, about $85 \%$ of breast CSs will report hot flushes, night sweats and arthralgia, resulting in multiple awakenings throughout the night $[62,63]$. Moreover, breast CSs with hot flushes and (joint) pain are respectively 2.25 (95\% CI 1.64-3.08) and 2.31 (95\% CI 1.36-3.92) more likely to develop sleep problems (Table 1, Figure 2) [64]. On the other hand, in non-cancer populations, insomnia forms a higher risk for developing future chronic pain disorders compared to chronic pain leading to new insomnia cases [65]. Sleep problems lower pain thresholds and exacerbate response to painful stimuli by dysregulating the immune system, hypothalamus-pituitary-adrenal axis, monoaminergic pathways, and endogenous substances (adenosine, nitric oxide, melatonin, and orexin), which will, for example, increase the pro-inflammatory state [66].

Based on compelling efficacy data, CBT for insomnia (CBT-I) is the gold standard treatment for insomnia (Figure 2) [67]. CBT-I addresses cognitive and behavioural factors that perpetuate insomnia using a multi-component treatment that includes sleep hygiene, stimulus control, sleep restriction, cognitive therapy and relaxation training [68]. The efficacy of CBT-I in CSs was investigated by a systematic review of Johnson et al., (2016) [57] in which they demonstrated that CBT-I improves insomnia symptom severity, sleep efficiency, sleep onset latency, and wake after sleep onset in CSs. The same research question was investigated specifically in breast CSs by a recent review of Ma et al., (2021) [69], in which moderate to large treatment effects were found with clinically significant effects lasting up to one year after therapy for insomnia symptom severity, sleep efficiency and sleep onset latency. Even though solid evidence has shown that CBT-I improves sleep in CSs [57], it remains underused and not readily available in the community or clinical settings [70]. Barriers on the provider level are a shortage of CBT-I specialists and a lack of physician training about sleep [71,72]. On the patient level, barriers include limited understanding of the consequences of insomnia, limited awareness of available treatment options and lack of treatment adherence due to the possible burdensome treatment format [73,74]. There is no doubt about the effectiveness of CBT-I in CSs. However, future studies are needed to investigate the optimal integration of the CBT-I components before adding to the pain management.

3.2.3. Diet

\section{Dietary Intake}

Dietary recommendations have only recently been brought into the picture for CSs treatment; therefore, the literature is sparse and limited to breast CSs. However, nutritional guidelines have been introduced by the National Cancer Institute, American Cancer Society, Academy of Nutrition to encourage CSs to start a healthy and prudent diet $[13,75]$. Unfortunately, the adherence is low because CSs have no guarantee that their prognosis will improve by adopting a healthy diet [76]. According to a meta-analysis of cohort 
studies, a Western diet, which is characterised by a high consumption of eggs, red meats, and processed foods, is associated with a higher risk of mortality (odds ratio $=1.51 ; 95 \%$ CI 1.24-1.85) and cancer recurrence (odds ratio $=1.34 ; 95 \%$ CI 0.61-2.92) in CSs [77]. However, weak evidence suggests that CSs may be able to reduce their mortality and cancer recurrence rate by switching to a healthy diet that consists of fruits, vegetables, fish, and whole grains after diagnosis [78]. A healthy diet is usually rich in anti-oxidative, antiinflammatory, endothelial protective, metabolic substances, which affect tumour growth and promote cancer apoptosis [79]. As advised by different associations, nutritional counselling should be provided by registered dietitians specialised in oncology [13].

Furthermore, ongoing research shows that food could have both an adverse and a beneficial influence on chronic pain. A recent systematic review revealed that studies examining whether diet influences chronic pain in CSs are essentially lacking (Table 1) [80]. Nevertheless, evidence in breast CSs points out some significant relation between pain and nutrition. A network meta-analysis for therapeutic options for aromatase inhibitorassociated arthralgia in breast cancer has suggested that omega- 3 fatty acids might be effective in reducing pain severity scores and pointed out the need for further evaluation for omega-3 fatty acids as well as vitamin D (Table 1) [81]. Additionally, a cross-sectional study showed clearly that breast CSs who were well-nourished or anabolic according to category A of the patient-generated subjective global assessment (PG-SGA) had fewer pain symptoms than those who were malnourished category B of PG-SGA [82].

As discussed earlier, nutritional sciences are only now beginning to address chronic pain in CSs. However, why should "diet" be advised in chronic pain management to CSs? Knowing the benefits and drawbacks of various diets for survivors with chronic pain could be the key to finding a clear answer. The most important vision of implementing a specific diet in pain management is based on using regulatory effects of nutrition on several pain mechanisms with no or bare minimum side effects. This could provide a long-term, sustainable, and cost-effective pain management alternative for CSs. Therefore, in the future, interdisciplinary collaboration across researchers and clinicians is needed to unravel the role of nutrition in pain-related mechanisms and its implications on pain reduction in CSs. Currently, the lack of evidence supporting the added value of dietary interventions for chronic pain management in CSs precludes to advise its use (Figure 2).

\section{Obesity}

Obesity is a condition characterised by an increase in body fat $[83,84]$. At the neurobiological level, obesity is considered to cause pain through various mechanisms, including inflammation and hormone imbalance [85]. At the mechanical level, obesity can also cause pain by structural overloading [84,86], which can lead to altered body posture and joint misuse [87]. The latest review in taxane- and platinum-treated CSs demonstrated a good-to-moderate relationship between obesity and higher severity or incidence of chemotherapy-induced peripheral neuropathy (CIPN), with moderate evidence showing diabetes did not increase incidence or severity of CIPN [88]. Furthermore, a systematic review with meta-analyses of Leysen et al., (2017) demonstrated that breast CSs with a $\mathrm{BMI}>30$ have a higher risk (odds ratio $=1.34,95 \%$ CI 1.08-1.67) of developing pain (Table 1, Figure 2) [12]. However, more research is needed to determine the long-term impact of obesity among the expanding population of CSs [89]. Studies looking at the link between changes in body mass index, fat mass, inflammatory markers, and chronic pain might help us better comprehend the relationship between these variables in the CS population. Additionally, well-designed, high-quality randomised controlled trials on the effect of combined weight loss/pain therapies are required to inform patients and clinicians on how to personalise the approach to reduce chronic pain prevalence, intensity, or severity in CSs through obesity management (Figure 2). 


\subsubsection{Smoking}

Smoking tobacco and, to a lesser extent, e-cigarettes is well-known to negatively influence cancer's prognosis and forms a major risk factor for various cancer types and several other chronic diseases [90-92]. Smoking cessation has a favourable effect on treatment efficacy, psychological well-being and general quality of life [93]. The National Comprehensive Cancer Network offers a guideline for smoking cessation, consisting of pharmacotherapy (e.g., nicotine replacement therapy or varenicline) and behaviour therapy (Figure 2) $[47,94]$. This program is more successful when initiated at the time of diagnosis because an early start avoids more adverse effects [90]. Patients who continue to smoke have a higher likelihood of facing post-operative complications due to (wound) infections, failed reconstruction and tissue necrosis, which could lead to prolonged hospitalisation [95,96]. Unfortunately, a big proportion of young CSs continue to smoke after their diagnosis. Approximately $25.2 \%$ of CSs aged 18 to 44 years were current smokers compared to $15.8 \%$ in the general population [97]. Thus, during the survivor phase, additional support should be provided to target patients' barriers to smoking cessation to prevent cancer recurrence.

Pain might be one of the barriers to smoking cessation in CSs [98]. An observational study by Aigner et al., (2016) demonstrated that when patients experience higher pain levels, they usually smoke a larger number of cigarettes during these days and initiate fewer attempts to quit smoking [98]. This can be explained by the fact that nicotine produces an acute analgesic effect, making it much harder for them to stop due to the rewarding sensation they experience [99]. Despite its short-term analgesic effect, tobacco smoking sustains pain in the long-term [93]. This underlines the importance of incorporating antismoking medications in CSs with pain to avoid relapse during nicotine withdrawal [99]. Moreover, pain management should be added to the counselling aspect to enhance the patient's knowledge, which in turn, might improve their adherence to the whole smoking cessation program [98]. Furthermore, the 5As (Ask, Advise, Assess, Assist, Arrange) approach, which assesses the willingness of the patient to quit smoking, is no longer recommended since studies have demonstrated that smokers who did not feel ready to quit smoking at the same rate as those who wanted to [100]. The model with the most promising results might be "opt-out", during which health care providers offer counselling and pharmacotherapy to all smokers, which is more ethical [101]. However, research on how to integrate this approach in current cancer care for CSs is needed.

\subsubsection{Alcohol Consumption}

Similar to smoking, alcohol consumption is a preventable risk factor for liver, oesophageal, colorectal, breast, head, neck, and many other cancers [102]. It is established that excessive or binge drinking enhances the likelihood of cancer recurrence, bad prognosis, or death [77]. Despite this, up to now, no evidence supports or refutes that drinking with moderation ( $\leq 1$ drink for women and $\leq 2$ drinks for men per day) is associated with a lower risk of cancer [103-105]. On top of this, some studies show a reduction in risk due to moderate alcohol intake, which might be explained by confounders, and/or the anti-cancer effect of polyphenols (present in wine) [106] or phytoestrogen and polysaccharides (present in beer) that lower free testosterone, inducing prostate cancer $[107,108]$. However, these small benefits are quickly outweighed by other harms of alcohol consumption. Furthermore, a growing trend in alcohol intake among CSs is observed, but no explanation for this trend could be found [109]. Nevertheless, alcohol consumption can initiate people to smoke or smoke even more [109]. Combining both multiplies their adverse effects because alcohol slows down the body's capacity to eliminate the carcinogenic chemicals of smoking $[97,109,110]$. These findings highlight the importance of increasing CSs' awareness about these lifestyle factors.

The impact of alcohol use on pain is poorly investigated in CSs, but according to one systematic review of two cohort studies, the risk of developing pain can be reduced by alcohol use (Table 1) [12]. This finding might be misleading due to the fact that alcohol has an acute analgesic effect [111]. In non-cancer populations, studies demonstrated that this 
analgesic effect diminishes over time, and there is an association between chronic pain and alcohol consumption [112]. This pain might be evoked by developing alcoholic neuropathy, musculoskeletal disorders, or alcohol withdrawal [112]. Conversely, chronic pain increases the risk of alcohol abuse [113]. Nevertheless, psychosocial factors are also highly present in patients with alcohol abuse and can be attributed to abnormalities in the reward system of the brain [114]. Additionally, a recently published study demonstrated that chronic pain patients with high levels of pain catastrophising are more likely to be heavy drinkers [115]. General advice on alcohol consumption after cancer is currently not possible due to the high variability of results in different CSs. Therefore, health care providers should tailor their advice according to cancer types and patients [116]. Within that view, an overview of recommendations regarding individualised alcohol consumption for each CS type could support clinicians in doing so, yet such evidence-based recommendations are currently lacking (Figure 2).

\subsubsection{Physical Activity}

Being physically active after a cancer diagnosis improves CSs' survival rate by $30 \%$ [117-119], which underlines that healthy behaviour during the extended survival phase is essential [117]. The American College of Sports Medicine, American Cancer Society and the US Department of Health and Human Services developed exercise guidelines that advise every CS to engage weekly in 75 min of vigorous-intensity or $150 \mathrm{~min}$ of moderateintensity aerobic physical activity $[90,120,121]$. For instance, the evidence demonstrated that supervised physical activity reduces cancer-related fatigue, depression, and increases quality of life, cardiovascular and musculoskeletal fitness in CSs [14-16]. Additional beneficial effects of physical activity were also seen on musculoskeletal pain and stiffness in breast CSs taking aromatase inhibitors for a long period (Table 1, Figure 2) [81,122,123]. However, only few CSs attain the recommended physical activity levels, with pain being an important limiting factor $[116,124]$. Inappropriate beliefs regarding the expected outcome of physical activity represent a major barrier for CSs to engage in physical activity programs. For example, some breast CSs fear that resistance exercises can aggravate cancer-related lymphedema, which is proven to be wrong as resistance exercises are perfectly safe in this group and do not increase lymphedema [125], others might fear that exercise can exacerbate their pain, which was refuted by systematic reviews with meta-analyses in CSs and a Cochrane review in chronic non-cancer pain populations, demonstrating that physical activity has a small positive effect on pain (Table 1, Figure 2) $[123,126,127]$. Despite all this evidence, patients' adherence to physical activity remains low and remains a bottleneck in current care [128]. Therefore, how to reduce a sedentary lifestyle in CSs with chronic pain should be more thoroughly investigated and implemented in guidelines, and patients should be better informed about the benefits of an active lifestyle [128].

Identifying predictors of adherence will offer the possibility to provide personalised guidance to CSs who are less likely to adhere to exercise, which will undoubtedly lead to better treatment outcomes [129]. According to a systematic review, behavioural (i.e., motivation) and sociodemographic predictors (i.e., distance and social support of the family or therapists) should be addressed [130]. To improve CSs' exercise motivation or lifestyle behaviours, motivational interviewing can be used [131]. During this patient-centred approach, five different stages can be distinguished: pre-contemplation, contemplation, preparation, action, and maintenance. In each stage, behaviour changes will be tackled differently [130,131]. A Cochrane review concluded that exercise interventions with determined goals, graded activity, and behaviour change reached the highest adherence in CSs [118]. Behavioural graded activity is such an intervention that combines these three components and aims (i.e., determined goals, graded activity, and behaviour change) to target patients' difficulties and complaints during their daily living [132]. This approach might enhance patients' willingness to adhere to healthy behaviour compared to other exercise interventions. Additionally, in recent years, alternative therapies such as mindfulnessbased approaches, hypnosis and yoga gained importance and demonstrated significant 
beneficial effects on quality of life, psychological distress, anxiety, depression, fear of cancer recurrence, fatigue, sleep, and pain [133-135]. Obviously, mindfulness-based approaches and yoga fit into the 'stress management' category as well, and therefore potentially serve two lifestyle factors (i.e., stress and physical therapy). However, more research is needed to find the optimal approach for higher long-term adherence to an active lifestyle in CSs.

Table 1. Evidence of lifestyle factors on pain in cancer survivors. Abbreviations: AIA: Aromatase Inhibitor-associated Arthralgia; C: Cohort; CI: Confidence Interval; CIPN: Chemotherapy-Induced Peripheral Neurotoxicity; CS: Cross-sectional Study; ES: Effect Size; I²: Heterogeneity; MD: Mean Difference; OR: Odds Ratio; $p$ : $p$-value; RCT: Randomized Controlled Trial; SMD: Standardized Mean Difference; SORT: Strength of Recommendation Taxonomy.

\begin{tabular}{|c|c|c|c|c|c|c|}
\hline $\begin{array}{l}\text { Lifestyle } \\
\text { Factor }\end{array}$ & $\begin{array}{l}\text { First Author, } \\
\text { Year Published, } \\
\text { Study Type }\end{array}$ & $\begin{array}{l}\text { Included } \\
\text { Population }\end{array}$ & $\begin{array}{l}\text { Number of Included } \\
\text { Studies }\left(\mathbf{n}_{1}\right) \text { and } \\
\text { Participants }\left(\mathbf{n}_{2}\right)\end{array}$ & $\begin{array}{c}\text { Detail } \\
\text { of Lifestyle Fac- } \\
\text { tor/Intervention } \\
\text { Assessed }\end{array}$ & $\begin{array}{l}\text { Main Results in } \\
\text { Context of the } \\
\text { Specified } \\
\text { State-of-the-Art }\end{array}$ & $\begin{array}{l}\text { Level of } \\
\text { Evidence } \\
\text { [136] }\end{array}$ \\
\hline $\begin{array}{l}\text { Alcohol con- } \\
\text { sumption }\end{array}$ & $\begin{array}{l}\text { Leysen et al., } \\
2017, \\
\text { Systematic } \\
\text { review with } \\
\text { meta-analysis } \\
\text { [12] }\end{array}$ & $\begin{array}{l}\text { Breast Cancer } \\
\text { Survivors }\end{array}$ & $\begin{array}{c}\mathrm{n}_{1}=2(1 \mathrm{CS} \text { and } 1 \mathrm{C}) \\
\text { and } \mathrm{n}_{2}=2519\end{array}$ & Alcohol use & $\begin{array}{c}\text { Alcohol (OR 0.94, } \\
95 \% \text { CI }[0.47,1.89] \\
\left.p=0.86, I^{2}=67 \%\right) \\
\text { was not a predictor } \\
\text { for pain, } \\
\text { Inconsistent and } \\
\text { low evidence }\end{array}$ & $3 b$ \\
\hline \multirow[t]{2}{*}{ Diet } & $\begin{array}{l}\text { Kim et al., 2018, } \\
\text { Systematic } \\
\text { review of } \\
\text { systematic } \\
\text { reviews [81] }\end{array}$ & $\begin{array}{c}\text { Breast Cancer } \\
\text { Survivors with } \\
\text { AIA }\end{array}$ & $\begin{array}{c}\mathrm{n}_{1}=3 \text { (systematic } \\
\text { review of RCT), and } \\
\mathrm{n}_{2 \_ \text {Omega-3 }}=817 \text {, and } \\
\mathrm{n}_{2 \_V D}=453\end{array}$ & $\begin{array}{l}\text { Omega-3 Fatty } \\
\text { Acids, and } \\
\text { Vitamin D }\end{array}$ & $\begin{array}{c}\text { Significant effects } \\
\text { were found for } \\
\text { omega-3 fatty acids } \\
\text { (MD }-2.10,95 \% \\
\text { CI }[-3.23,-0.97]) \\
\text { and vitamin D (MD } \\
0.63,95 \% \\
\text { CI [0.13, } 1.13]) \text { on } \\
\text { pain, Low evidence }\end{array}$ & $1 \mathrm{a}$ \\
\hline & $\begin{array}{c}\text { Yilmaz et al., } \\
2021, \\
\text { Systematic } \\
\text { review [80] }\end{array}$ & $\begin{array}{l}\text { Cancer } \\
\text { Survivors }\end{array}$ & $\begin{array}{c}\mathrm{n}_{1}=2 \text { (uncontrolled } \\
\text { clinical trial) and } \\
\mathrm{n}_{2}=77\end{array}$ & $\begin{array}{l}\text { Nutritional } \\
\text { supplements: } \\
\text { vitamin C, } \\
\text { chondroitin, } \\
\text { and } \\
\text { glucosamine }\end{array}$ & Lack of evidence & $2 a$ \\
\hline \multirow{2}{*}{ Obesity } & $\begin{array}{l}\text { Leysen et al., } \\
2017, \\
\text { Systematic } \\
\text { review with } \\
\text { meta-analysis } \\
\text { [12] }\end{array}$ & $\begin{array}{l}\text { Breast Cancer } \\
\text { Survivors }\end{array}$ & $\begin{array}{c}\mathrm{n}_{1}=7(4 \mathrm{CS} \text { and } 3 \mathrm{C}) \\
\text { and } \mathrm{n}_{2}=5573\end{array}$ & BMI & $\begin{array}{c}\text { BMI > } 30(\mathrm{OR} 1.34, \\
95 \% \mathrm{CI}[1.08,1.67], \\
p=0.008, \mathrm{I}^{2}=33 \%, \\
\text { was a predictor for } \\
\text { pain, Consistent } \\
\text { and low evidence }\end{array}$ & $3 b$ \\
\hline & $\begin{array}{c}\text { Timmins et al., } \\
\text { 2021, } \\
\text { Systematic } \\
\text { review [88] }\end{array}$ & $\begin{array}{l}\text { Cancer } \\
\text { Survivors }\end{array}$ & $\begin{array}{c}\mathrm{n}_{1}=16(3 \mathrm{CS}, 11 \mathrm{C}, \\
\text { and } 2 \text { retrospective } \\
\text { chart review }) \text { and } \\
\mathrm{n}_{2}=14,033\end{array}$ & Obesity & $\begin{array}{l}\text { According to the } \\
\text { SORT: the } \\
\text { association } \\
\text { between obesity } \\
\text { and CIPN was } \\
\text { good-to-moderate } \\
\text { patient-centred } \\
\text { evidence }\end{array}$ & $3 b$ \\
\hline
\end{tabular}


Table 1. Cont.

\begin{tabular}{|c|c|c|c|c|c|c|}
\hline $\begin{array}{l}\text { Lifestyle } \\
\text { Factor }\end{array}$ & $\begin{array}{l}\text { First Author, } \\
\text { Year Published, } \\
\text { Study Type }\end{array}$ & $\begin{array}{l}\text { Included } \\
\text { Population }\end{array}$ & $\begin{array}{l}\text { Number of Included } \\
\text { Studies }\left(\mathrm{n}_{1}\right) \text { and } \\
\text { Participants }\left(\mathrm{n}_{2}\right)\end{array}$ & $\begin{array}{c}\text { Detail } \\
\text { of Lifestyle Fac- } \\
\text { tor/Intervention } \\
\text { Assessed }\end{array}$ & $\begin{array}{l}\text { Main Results in } \\
\text { Context of the } \\
\text { Specified } \\
\text { State-of-the-Art }\end{array}$ & $\begin{array}{c}\text { Level of } \\
\text { Evidence } \\
\text { [136] }\end{array}$ \\
\hline \multirow{5}{*}{$\begin{array}{l}\text { Physical } \\
\text { Activity }\end{array}$} & $\begin{array}{l}\text { Boing et al., } \\
\text { 2020, } \\
\text { Systematic } \\
\text { review with } \\
\text { meta-analysis } \\
\text { [123] }\end{array}$ & $\begin{array}{l}\text { Breast Cancer } \\
\text { Survivors with } \\
\text { AIA }\end{array}$ & $\begin{array}{l}\mathrm{n}_{1}=3(2 \mathrm{RCT}, 1 \text { pilot } \\
\text { study }) \text {, and } \mathrm{n}_{2}=118\end{array}$ & Exercise & $\begin{array}{c}\text { Significant effect } \\
\text { was found } \\
\text { on pain (SMD } \\
-0.55,95 \% \text { CI } \\
{[-1.11,-0.00]} \\
\left.p=0.05 \mathrm{I}^{2}=80 \%\right), \\
\text { Low Evidence }\end{array}$ & $1 b$ \\
\hline & $\begin{array}{c}\text { Kim et al., 2018, } \\
\text { Systematic } \\
\text { review of } \\
\text { systematic } \\
\text { reviews [81] }\end{array}$ & $\begin{array}{l}\text { Breast Cancer } \\
\text { Survivors with } \\
\text { AIA }\end{array}$ & $\begin{array}{c}\mathrm{n}_{1}=2 \text { (systematic } \\
\text { review of RCT), and } \\
\mathrm{n}_{2}=262\end{array}$ & $\begin{array}{l}\text { Aerobic } \\
\text { Exercise }\end{array}$ & $\begin{array}{l}\text { No significant } \\
\text { effect was found on } \\
\text { pain }(\mathrm{MD}-0.80,95 \% \\
\text { CI }[-1.33,0.016]), \\
\text { Low evidence }\end{array}$ & $1 \mathrm{a}$ \\
\hline & $\begin{array}{l}\text { Lavín-Pérez } \\
\text { et al., 2021, } \\
\text { Systematic } \\
\text { review with } \\
\text { meta-analysis } \\
\text { [127] }\end{array}$ & $\begin{array}{l}\text { Cancer } \\
\text { Survivors }\end{array}$ & $\begin{array}{c}\mathrm{n}_{1}=7(\mathrm{RCT}), \text { and } \mathrm{n}_{2} \\
=355\end{array}$ & Exercise (HIT) & $\begin{array}{c}\text { Significant effect } \\
\text { was found on pain } \\
(\mathrm{SMD}-0.18,95 \% \\
\mathrm{CI}[-0.34,-0.02] \\
\left.p=0.02, \mathrm{I}^{2}=4 \%\right) \\
\text { Moderate evidence }\end{array}$ & $1 \mathrm{a}$ \\
\hline & $\begin{array}{l}\text { Lu et al., 2020, } \\
\text { Systematic } \\
\text { review with } \\
\text { meta-analysis } \\
\text { [122] }\end{array}$ & $\begin{array}{c}\text { Breast Cancer } \\
\text { Survivors with } \\
\text { AIA }\end{array}$ & $\begin{array}{c}\mathrm{n}_{1}=6(\mathrm{RCT}), \text { and } \mathrm{n}_{2} \\
=416\end{array}$ & Exercise & $\begin{array}{c}\text { Significant effect } \\
\text { was found on pain } \\
\text { (SMD }-0.46,95 \% \\
\text { CI }[-0.79,-0.13] \\
\left.p=0.006, \mathrm{I}^{2}=63 \%\right), \\
\text { Moderate evidence }\end{array}$ & $1 \mathrm{a}$ \\
\hline & $\begin{array}{c}\text { Timmins et al., } \\
\text { 2021, } \\
\text { Systematic } \\
\text { review [88] }\end{array}$ & $\begin{array}{l}\text { Cancer } \\
\text { Survivors }\end{array}$ & $\begin{array}{c}\mathrm{n}_{1}=5(2 \mathrm{C} \text { and } 3 C S) \\
\text { and } \mathrm{n}_{2}=3950\end{array}$ & $\begin{array}{l}\text { Low physical } \\
\text { activity }\end{array}$ & $\begin{array}{l}\text { According to the } \\
\text { SORT: the } \\
\text { association } \\
\text { between physical } \\
\text { inactivity and } \\
\text { CIPN was of } \\
\text { moderate evidence }\end{array}$ & $3 b$ \\
\hline Sleep & $\begin{array}{l}\text { Leysen et al., } \\
2019, \\
\text { Systematic } \\
\text { review with } \\
\text { meta-analysis } \\
\text { [64] }\end{array}$ & $\begin{array}{l}\text { Breast Cancer } \\
\text { Survivors }\end{array}$ & $\begin{array}{c}\mathrm{n}_{1}=4(2 \mathrm{CS} \text { and } 2 \mathrm{C}) \\
\text { and } \mathrm{n}_{2}=1907\end{array}$ & $\begin{array}{c}\text { Sleep } \\
\text { Disturbances }\end{array}$ & $\begin{array}{c}\text { Pain was a } \\
\text { predictor for sleep } \\
\text { disturbances (OR } \\
1.68,95 \% \\
\text { CI }[1.19,2.37], \\
p=0.05, \mathrm{I}^{2}=55 \%, \\
\text { after subgroup } \\
\text { analysis OR } 2.31, \\
95 \% \text { CI }[1.36,3.92], \\
\left.p=0.002, \mathrm{I}^{2}=27 \%\right)\end{array}$ & $3 b$ \\
\hline Smoking & $\begin{array}{l}\text { Leysen et al., } \\
2017, \\
\text { Systematic } \\
\text { review with } \\
\text { meta-analysis } \\
\text { [12] }\end{array}$ & $\begin{array}{l}\text { Breast Cancer } \\
\text { Survivors }\end{array}$ & $\begin{array}{c}\mathrm{n}_{1}=2(1 \mathrm{CS} \text { and } 1 \mathrm{C}) \\
\text { and } \mathrm{n}_{2}=2519\end{array}$ & Smoking status & $\begin{array}{c}\text { Smoking (OR 0.75, } \\
95 \% \text { CI [0.62, 0.92], } \\
\left.p=0.005, \mathrm{I}^{2}=0 \%\right) \\
\text { was not a predictor } \\
\text { for pain, Consistent } \\
\text { and low evidence }\end{array}$ & $3 b$ \\
\hline
\end{tabular}


Table 1. Cont.

\begin{tabular}{|c|c|c|c|c|c|c|}
\hline $\begin{array}{l}\text { Lifestyle } \\
\text { Factor }\end{array}$ & $\begin{array}{l}\text { First Author, } \\
\text { Year Published, } \\
\text { Study Type }\end{array}$ & $\begin{array}{l}\text { Included } \\
\text { Population }\end{array}$ & $\begin{array}{l}\text { Number of Included } \\
\text { Studies }\left(\mathbf{n}_{1}\right) \text { and } \\
\text { Participants }\left(\mathbf{n}_{2}\right)\end{array}$ & $\begin{array}{c}\text { Detail } \\
\text { of Lifestyle Fac- } \\
\text { tor/Intervention } \\
\text { Assessed }\end{array}$ & $\begin{array}{l}\text { Main Results in } \\
\text { Context of the } \\
\text { Specified } \\
\text { State-of-the-Art }\end{array}$ & $\begin{array}{l}\text { Level of } \\
\text { Evidence } \\
\text { [136] }\end{array}$ \\
\hline Stress & $\begin{array}{c}\text { Syrowatka } \\
\text { et al., 2017, } \\
\text { Systematic } \\
\text { review } \\
\text { [42] }\end{array}$ & $\begin{array}{l}\text { Breast Cancer } \\
\text { Survivors }\end{array}$ & $\begin{array}{c}\mathrm{n}_{1}=12(6 \mathrm{CS} \text { and } 6 \mathrm{C}) \\
\text { and } \mathrm{n}_{2}=7842\end{array}$ & Distress & $\begin{array}{c}\text { Pain was } \\
\text { significantly } \\
\text { associated with } \\
\text { distress: } 9 / 12 \\
\text { studies }(75 \%)\end{array}$ & $3 b$ \\
\hline \multirow{4}{*}{ Intervention } & $\begin{array}{l}\text { Chang et al., } \\
2020, \\
\text { Systematic } \\
\text { review with } \\
\text { meta-analysis } \\
\text { [54] }\end{array}$ & $\begin{array}{l}\text { Breast Cancer } \\
\text { Survivors }\end{array}$ & $\begin{array}{l}\mathrm{n}_{1}=5(\mathrm{RCT}) \\
\text { and } \mathrm{n}_{2}=827\end{array}$ & $\begin{array}{l}\text { Mindfulness- } \\
\text { Based } \\
\text { interventions }\end{array}$ & $\begin{array}{c}\text { No significant } \\
\text { effect was found } \\
\text { on pain } \\
\text { (SMD }-0.39,95 \% \\
\text { CI, }[-0.81,0.03] \\
\left.p=0.07, \mathrm{I}^{2}=85 \%\right), \\
\text { Moderate evidence }\end{array}$ & $1 \mathrm{a}$ \\
\hline & $\begin{array}{c}\text { Cillessen et al., } \\
2019, \\
\text { Systematic } \\
\text { review with } \\
\text { meta-analysis } \\
\text { [133] }\end{array}$ & $\begin{array}{l}\text { Cancer Patients } \\
\text { and Survivors }\end{array}$ & $\begin{array}{l}\mathrm{n}_{1}=4(\mathrm{RCT}) \\
\text { and } \mathrm{n}_{2}=587\end{array}$ & $\begin{array}{l}\text { Mindfulness- } \\
\text { Based } \\
\text { interventions }\end{array}$ & $\begin{array}{c}\text { Significant effect } \\
\text { was found on pain } \\
(\text { ES } 0.2,95 \% \text { CI } \\
{[0.04,0.36], p=0.16} \\
\left.\mathrm{I}^{2}=0 \%\right), \text { Moderate } \\
\text { evidence }\end{array}$ & 1a \\
\hline & $\begin{array}{l}\text { Martinez- } \\
\text { Miranda } \\
\text { [26] }\end{array}$ & $\begin{array}{l}\text { Breast Cancer } \\
\text { Survivors }\end{array}$ & $\begin{array}{l}\mathrm{n}_{1}=2(\mathrm{RCT}) \\
\text { and } \mathrm{n}_{2}=134\end{array}$ & $\begin{array}{l}\text { Patient } \\
\text { Education }\end{array}$ & $\begin{array}{c}\text { No significant } \\
\text { effect was found } \\
\text { on pain } \\
\text { (SMD }-0.05,95 \% \\
\text { CI }[-0.26,0.17] \\
p=0.67, \mathrm{I}^{2}=0 \%, \\
\text { Low evidence }\end{array}$ & $1 \mathrm{a}$ \\
\hline & $\begin{array}{l}\text { Silva et al., 2019, } \\
\text { Systematic } \\
\text { review [137] }\end{array}$ & $\begin{array}{l}\text { Cancer } \\
\text { Survivors }\end{array}$ & $\begin{array}{c}\mathrm{n}_{1}=4(4 \\
\text { quasi-experimental } \\
\text { studies), and } \mathrm{n}_{2}=522\end{array}$ & $\begin{array}{l}\text { Promoting } \\
\text { healthy } \\
\text { behaviour by } \\
\text { mHealth apps }\end{array}$ & $\begin{array}{l}\text { Effect found on } \\
\text { pain was } \\
\text { inconsistent and of } \\
\text { low quality of } \\
\text { evidence }\end{array}$ & $2 b$ \\
\hline
\end{tabular}

\section{Future Directions for Scientists}

First, it is recommended that researchers make a clear distinction between CSs' phases when initiating and reporting studies in CSs. Currently, the term CS is too globally used, making it difficult to compare or combine results of studies due to their high heterogeneity. An individual in palliative care has different needs than an individual that is cured of cancer; however, both are CSs according to the most widely used definition [4]. A distinction between the different phases has been described by Mullan et al., in 1985 [138]. Unfortunately, these terms are not frequently used in the literature [138] even though a clear distinction between phases could help clinicians to communicate more easily and to provide the appropriate care to patients' needs according to their phase in the survival of cancer.

Second, most studies were performed on Caucasian breast CSs with high socioeconomic status. This population is more likely to have a higher adherence and willingness to change their lifestyle habits [139]. However, to reach a better understanding of barriers for lifestyle changes, research needs to be performed among CS populations with diverse socio-economic backgrounds. This way, oncological care for CSs can be more tailored to patients of different gender, race, and socio-economic capacities.

Third, future studies regarding lifestyle factors in CSs should more thoroughly account for possible confounders. Indeed, research studying a particular lifestyle factor should not 
only be adjusted for age, gender, education, and so forth, but also for other established lifestyle factors, which might be a considerable confounder. Furthermore, the effects of lifestyle factors in CSs are most often observed over a short period, preventing to draw conclusions regarding long-term impact of lifestyle factors in CSs. More research is warranted to observe the long-term effects of pain management and healthy lifestyle interventions in CSs.

\section{Future Directions for Clinicians}

The literature indicates that implementing healthy lifestyle habits in CSs has low compliance rates [140]. A barrier that might cause low adherence to healthy lifestyle behaviours is the burdensome treatment format of most behavioural interventions [73,74]. Therefore, stepped care models might provide clinicians with a possible solution to improve the feasibility and deliver care efficiently [141]. In existing stepped care models, the first step is typically a form of self-management therapy (e.g., recommendations) with the possibility to progress to the highest step of six to eight individual sessions with a specialist, if needed $[142,143]$. For example, a recent study in CSs demonstrated that more than 50\% of CSs with insomnia benefit form a one-hour group-delivered session that empowers CSs by teaching them about sleep health and provides specific information on how to adapt their sleep behaviours [142]. Interestingly, they found that CSs who had experienced sleep problems for a shorter period and perceived less burden from their sleep problems were most likely to benefit from the one-hour program, suggesting that it is crucial to identify CS with sleep problems as soon as possible to enhance the efficacy of low-intensity interventions [142]. However, further research is warranted before implementing stepped care for the other lifestyle factors. In addition, systematic reviews demonstrated promising findings for virtual therapy, suggesting that virtual interventions might be a possible option to enhance access to care, which solves the distance issue $[69,137,144]$.

Furthermore, to reduce the treatment burden, clinicians should perform early screenings and identify negative predictors to improve patients' self-efficacy to sustain a healthy lifestyle. Developing evidence-based guidelines, including algorithms with practical triage and referral plans to other healthcare professionals, will improve survivorship care. Enhancing the productivity of oncological care by 2025 is of utmost importance because there will be a shortage of oncologists due to the growing cancer population [145]. Besides that, many clinicians have difficulties providing the ideal pain management plan and delivering health promotion guidance due to a lack of knowledge [22]. Supplementary support and educational interventions should be organized for health care providers to enhance their expertise and confidence in this field.

Another recommendation for future clinical practice is considering the use of pain neuroscience education as a way to decrease the threatening nature of pain, catastrophic thinking and fear-avoidance beliefs in CSs [146]. Cancer patients indicate themselves that they have insufficient knowledge regarding pain during or after cancer, what the possibilities of pain relief are and how they can access support when needed [24,25]. When comparing pain knowledge between CSs, healthy controls and caregivers, CSs had the lowest pain knowledge of the three groups [147]. Education about pain is underused in the field of oncology and non-existent in the survivorship phase [148]. Pain neuroscience education can clear the path for more active approaches to pain management, including providing lifestyle interventions. Manuals with guidelines for clinicians on how to explain pain following cancer [146], including accounting for perceived injustice during pain neuroscience education [149], are available to support clinicians in doing so.

Lastly, this state-of-the-art paper underlines once more the complexity of managing chronic pain in CSs. As discussed previously, adopting a healthy lifestyle might have a beneficial influence on the chronic pain of CSs. Unfortunately, there is currently a lack of research about the effectiveness of modifiable lifestyle factors on pain. Moreover, pain in CSs should be targeted on cognitive, behavioural, sensory and emotional levels due 
to its complexity [18]. Therefore, all pain interventions should be multidisciplinary and personalized for each CS [19].

\section{Conclusions}

Emerging evidence shows that CSs find it challenging to receive optimal treatment plans for their burdens, and support or reinforcement to maintain a healthy lifestyle. Therefore, it is crucially important to prepare clinicians well, so they can provide guidance along and after primary treatment. For chronic pain in CSs, it is primordial to identify factors that contribute to the transition of acute to chronic pain in CSs because chronic pain remains underrecognized and mistreated in this population. Furthermore, a proper definition between CSs' phases should be developed for optimal research and treatment. In the clinical field, new psychosocial factors and modifiable lifestyle factors should be targeted to improve pain relief in CSs.

Modifiable lifestyle factors and their impact on pain have been discussed in depth in this paper and are, for instance, stress, insomnia, diet, obesity, smoking, alcohol consumption and physical activity. First, an inappropriate stress response promotes pain by dysregulating the autonomic, endocrine, and immune response creating a problematic back loop because pain is a manageable risk factor for distress. The stress response can be managed by CBSM, CBT, MBSR and yoga. Second, sleep and pain also form a vicious cycle (sleep problems exacerbate response to nociceptive stimuli and pain can disturb sleep quality) that CBT-I can break. Third, guidelines recommend prudent diets in CSs. However, more research is needed to unravel the role of nutrition and obesity in CSs. Fourth, alcohol consumption and smoking are both negative lifestyle behaviours that impact patients' general health. Smoking cessation should consist of behaviour therapy and medication. Last, physical activity demonstrates its beneficial impact in several systematic reviews. However, the adherence is low and new treatment strategies such as motivational interviewing or BGA should be investigated in CSs to increase treatment outcomes in the long-term.

In the future, there will be an insufficient number of professionals (oncologists) due to the growing cancer population $[150,151]$. Therefore, it is a priority that researchers refine current treatment plans and define the benefits of modifiable lifestyle factors and their impact on chronic pain in CSs.

Author Contributions: Conceptualization, A.L., E.R. (Eva Roose), L.L., S.T.Y., K.M., F.R., E.R. (Emma Rheel), D.B., and J.N.; methodology, A.L. and J.N.; software, A.L.; validation, A.L., E.R. (Eva Roose), L.L., S.T.Y., K.M., F.R., E.R. (Emma Rheel), D.B., and J.N.; investigation, A.L., E.R. (Eva Roose), L.L., S.T.Y., and J.N.; writing—original draft preparation, A.L., E.R. (Eva Roose), L.L., S.T.Y., K.M., F.R., E.R. (Emma Rheel), D.B., and J.N.; writing-review and editing, A.L., L.L., S.T.Y., F.R., and J.N.; visualization, A.L.; funding acquisition, A.L., E.R. (Eva Roose), L.L., S.T.Y., E.R. (Emma Rheel), and J.N. All authors have read and agreed to the published version of the manuscript.

Funding: A.L. is a research fellow funded by the Research Foundation Flanders (Fonds Wetenschappelijk Onderzoek-FWO), Belgium (grant number 11B1920N). E.R. is funded by Stand Up to Cancer (Kom op tegen Kanker-KOTK), a Belgian cancer charity (project code ANI251). L.L. is a postdoctoral research fellow appointed on 2 funded projects, one by the Research Foundation Flanders (FWO) (grant number G040919N) and one by Stand up to Cancer (KOTK-project code ANI251). S.T.Y. is funded by the Ministry of National Education of the Turkish State as scholarship student for her Ph.D. research program. J.N. and E.R. are holders of a chair on oncological rehabilitation funded by the Berekuyl Academy/European College for Decongestive Lymphatic Therapy, the Netherlands.

Institutional Review Board Statement: Not applicable.

Informed Consent Statement: Not applicable.

Data Availability Statement: Not applicable.

Acknowledgments: We thank K. Ickmans (Vrije Universiteit Brussel) for creating Figure 1 with BioRender.com. 
Conflicts of Interest: The authors declare no conflict of interest. The funders had no role in the design of the study; in the collection, analyses, or interpretation of data; in the writing of the manuscript, or in the decision to publish the results.

\section{References}

1. Mahase, E. Cancer ovet alertakes CVD to become leading cause of death in high income countries. BMJ 2019, 366, 15368. [CrossRef]

2. Sung, H.; Ferlay, J.; Siegel, R.; Laversanne, M.; Soerjomataram, I.; Jemal, A.; Bray, F. Global Cancer Statistics 2020: GLOBOCAN Estimates of Incidence and Mortality Worldwide for 36 Cancers in 185 Countries. CA Cancer J. Clin. 2021, 71, 209-249. [CrossRef] [PubMed]

3. Viale, P.H. The American Cancer Society's facts \& figures: 2020 edition. J. Adv. Pract. Oncol. 2020, 11, 135.

4. Marzorati, C.; Riva, S.; Pravettoni, G. Who Is a Cancer Survivor? A Systematic Review of Published Definitions. J. Cancer Educ. 2017, 32, 228-237. [CrossRef] [PubMed]

5. Pachman, D.R.; Barton, D.L.; Swetz, K.M.; Loprinzi, C.L. Troublesome symptoms in cancer survivors: Fatigue, insomnia, neuropathy, and pain. J. Clin. Oncol. 2012, 30, 3687-3696. [CrossRef] [PubMed]

6. Van den Beuken-van Everdingen, M.H.; Hochstenbach, L.M.; Joosten, E.A.; Tjan-Heijnen, V.C.; Janssen, D.J. Update on Prevalence of Pain in Patients With Cancer: Systematic Review and Meta-Analysis. J. Pain Symptom Manag. 2016, 51, 1070-1090.e9. [CrossRef]

7. Bennett, M.I.; Kaasa, S.; Barke, A.; Korwisi, B.; Rief, W.; Treede, R.D. The IASP classification of chronic pain for ICD-11: Chronic cancer-related pain. Pain 2019, 160, 38-44. [CrossRef]

8. Tevaarwerk, A.; Denlinger, C.S.; Sanft, T.; Ansbaugh, S.M.; Armenian, S.; Baker, K.S.; Broderick, G.; Day, A.; Demark-Wahnefried, W.; Dickinson, K.; et al. Survivorship, Version 1.2021: Featured Updates to the NCCN Guidelines. J. Natl. Compr. Cancer Netw. 2021, 19, 676-685. [CrossRef] [PubMed]

9. Paice, J.A.; Portenoy, R.; Lacchetti, C.; Campbell, T.; Cheville, A.; Citron, M.; Constine, L.S.; Cooper, A.; Glare, P.; Keefe, F. Management of Chronic Pain in Survivors of Adult Cancers: American Society of Clinical Oncology Clinical Practice Guideline. J. Clin. Oncol. 2016, 34, 3325-3345. [CrossRef]

10. Moloney, N.A.; Pocovi, N.C.; Dylke, E.S.; Graham, P.L.; De Groef, A. Psychological Factors Are Associated with Pain at All Time Frames After Breast Cancer Surgery: A Systematic Review with Meta-Analyses. Pain Med. 2021, 22, 915-947. [CrossRef]

11. Wang, L.; Guyatt, G.H.; Kennedy, S.A.; Romerosa, B.; Kwon, H.Y.; Kaushal, A.; Chang, Y.; Craigie, S.; de Almeida, C.P.B.; Courban, R.J.; et al. Predictors of persistent pain after breast cancer surgery: A systematic review and meta-analysis of observational studies. CMAJ 2016, 188, E352-E361. [CrossRef]

12. Leysen, L.; Beckwée, D.; Nijs, J.; Pas, R.; Bilterys, T.; Vermeir, S.; Adriaenssens, N. Risk factors of pain in breast cancer survivors: A systematic review and meta-analysis. Support. Care Cancer 2017, 25, 3607-3643. [CrossRef]

13. Demark-Wahnefried, W.; Rogers, L.Q.; Alfano, C.M.; Thomson, C.A.; Courneya, K.S.; Meyerhardt, J.A.; Stout, N.L.; Kvale, E.; Ganzer, H.; Ligibel, J.A. Practical clinical interventions for diet, physical activity, and weight control in cancer survivors. $C A$ Cancer J. Clin. 2015, 65, 167-189. [CrossRef]

14. Meneses-Echávez, J.F.; González-Jiménez, E.; Ramírez-Vélez, R. Effects of supervised exercise on cancer-related fatigue in breast cancer survivors: A systematic review and meta-analysis. BMC Cancer 2015, 15, 77. [CrossRef]

15. Kessels, E.; Husson, O.; van der Feltz-Cornelis, C.M. The effect of exercise on cancer-related fatigue in cancer survivors: A systematic review and meta-analysis. Neuropsychiatr. Dis. Treat. 2018, 14, 479-494. [CrossRef] [PubMed]

16. Fuller, J.T.; Hartland, M.C.; Maloney, L.T.; Davison, K. Therapeutic effects of aerobic and resistance exercises for cancer survivors: A systematic review of meta-analyses of clinical trials. Br. J. Sports Med. 2018, 52, 1311. [CrossRef] [PubMed]

17. Bobyrov, V. Bases of Bioethics and Biosafety: Study Guide for Stud. of Higher Med. Est; Нова Книга: Vinnytsia, Ukraine, 2012.

18. Maindet, C.; Burnod, A.; Minello, C.; George, B.; Allano, G.; Lemaire, A. Strategies of complementary and integrative therapies in cancer-related pain-attaining exhaustive cancer pain management. Support. Care Cancer 2019, 27, 3119-3132. [CrossRef] [PubMed]

19. Glare, P.A.; Davies, P.S.; Finlay, E.; Gulati, A.; Lemanne, D.; Moryl, N.; Oeffinger, K.C.; Paice, J.A.; Stubblefield, M.D.; Syrjala, K.L. Pain in cancer survivors. J. Clin. Oncol. 2014, 32, 1739. [CrossRef]

20. Brown, M.R.; Ramirez, J.D.; Farquhar-Smith, P. Pain in cancer survivors. Br. J. Pain 2014, 8, 139-153. [CrossRef]

21. Sun, V.; <monospace $></$ monospace $>$ Borneman, T.; Piper, B.; Koczywas, M.; Ferrell, B. Barriers to pain assessment and management in cancer survivorship. J. Cancer Surviv. 2008, 2, 65-71. [CrossRef]

22. Chow, R.; Saunders, K.; Burke, H.; Belanger, A.; Chow, E. Needs assessment of primary care physicians in the management of chronic pain in cancer survivors. Support. Care Cancer 2017, 25, 3505-3514. [CrossRef]

23. Oldenmenger, W.H.; Geerling, J.I.; Mostovaya, I.; Vissers, K.C.; de Graeff, A.; Reyners, A.K.; van der Linden, Y.M. A systematic review of the effectiveness of patient-based educational interventions to improve cancer-related pain. Cancer Treat. Rev. 2018, 63, 96-103. [CrossRef]

24. Binkley, J.M.; Harris, S.R.; Levangie, P.K.; Pearl, M.; Guglielmino, J.; Kraus, V.; Rowden, D. Patient perspectives on breast cancer treatment side effects and the prospective surveillance model for physical rehabilitation for women with breast cancer. Cancer 2012, 118, 2207-2216. [CrossRef]

25. McGuire, D.B. Occurrence of cancer pain. J. Natl. Cancer Inst. Monogrphs 2004, 2004, 51-56. [CrossRef] [PubMed]

26. Martínez-Miranda, P.; Casuso-Holgado, M.J.; Jiménez-Rejano, J.J. Effect of patient education on quality-of-life, pain and fatigue in breast cancer survivors: A systematic review and meta-analysis. Clin. Rehabil. 2021, 35, 1722-1742. [CrossRef] [PubMed] 
27. Boland, E.G.; Ahmedzai, S.H. Persistent pain in cancer survivors. Curr. Opin. Support Palliat. Care 2017, 11, 181-190. [CrossRef] [PubMed]

28. Ong, W.Y.; Stohler, C.S.; Herr, D.R. Role of the Prefrontal Cortex in Pain Processing. Mol. Neurobiol. 2019, 56, 1137-1166. [CrossRef]

29. Sullivan, M.J.; Scott, W.; Trost, Z. Perceived injustice: A risk factor for problematic pain outcomes. Clin. J. Pain. 2012, 28, 484-488. [CrossRef]

30. Sullivan, M.J.; Davidson, N.; Garfinkel, B.; Siriapaipant, N.; Scott, W. Perceived injustice is associated with heightened pain behavior and disability in individuals with whiplash injuries. Psychol. Inj. Law 2009, 2, 238-247. [CrossRef]

31. Carriere, J.S.; Donayre Pimentel, S.; Yakobov, E.; Edwards, R.R. A Systematic Review of the Association Between Perceived Injustice and Pain-Related Outcomes in Individuals with Musculoskeletal Pain. Pain Med. 2020, 21, 1449-1463. [CrossRef]

32. Leysen, L.; Cools, W.; Nijs, J.; Adriaenssens, N.; Pas, R.; van Wilgen, C.P.; Bults, R.; Roose, E.; Lahousse, A.; Beckwée, D. The mediating effect of pain catastrophizing and perceived injustice in the relationship of pain on health-related quality of life in breast cancer survivors. Support. Care Cancer 2021, 29, 5653-5661. [CrossRef] [PubMed]

33. Carriere, J.S.; Martel, M.O.; Kao, M.C.; Sullivan, M.J.; Darnall, B.D. Pain behavior mediates the relationship between perceived injustice and opioid prescription for chronic pain: A Collaborative Health Outcomes Information Registry study. J. Pain Res. 2017, 10, 557-566. [CrossRef]

34. Turk, D.C.; Okifuji, A. What factors affect physicians' decisions to prescribe opioids for chronic noncancer pain patients? Clin. J. Pain 1997, 13, 330-336. [CrossRef]

35. Paice, J.A. Chronic treatment-related pain in cancer survivors. Pain 2011, 152, S84-S89. [CrossRef]

36. Derksen, J.W.G.; Beijer, S.; Koopman, M.; Verkooijen, H.M.; van de Poll-Franse, L.V.; May, A.M. Monitoring potentially modifiable lifestyle factors in cancer survivors: A narrative review on currently available methodologies and innovations for large-scale surveillance. Eur. J. Cancer 2018, 103, 327-340. [CrossRef]

37. Gopalakrishna, A.; Longo, T.A.; Fantony, J.J.; Van Noord, M.; Inman, B.A. Lifestyle factors and health-related quality of life in bladder cancer survivors: A systematic review. J Cancer Surviv. 2016, 10, 874-882. [CrossRef]

38. Fink, G. Stress: Concepts, Cognition, Emotion, and Behavior; Academic Press Elsevier: Cambridge, MA, USA, 2007.

39. Tsigos, C.; Kyrou, I.; Kassi, E.; Chrousos, G.P. Stress: Endocrine Physiology and Pathophysiology. In Endotext; Feingold, K.R., Anawalt, B., Boyce, A., Chrousos, G., de Herder, W.W., Dhatariya, K., Dungan, K., Hershman, J.M., Hofland, J., Kalra, S., et al., Eds.; MDText.com: South Dartmouth, MA, USA, 2000.

40. National Research Council Committee on, R. and A. Alleviation of Distress in Laboratory, The National Academies Collection: Reports funded by National Institutes of Health. In Recognition and Alleviation of Distress in Laboratory Animals; National Academies Press: Washington, DC, USA, 2008.

41. Abbey, G.; Thompson, S.B.N.; Hickish, T.; Heathcote, D. A meta-analysis of prevalence rates and moderating factors for cancer-related post-traumatic stress disorder. Psychooncology 2015, 24, 371-381. [CrossRef]

42. Syrowatka, A.; Motulsky, A.; Kurteva, S.; Hanley, J.A.; Dixon, W.G.; Meguerditchian, A.N.; Tamblyn, R. Predictors of distress in female breast cancer survivors: A systematic review. Breast Cancer Res. Treat 2017, 165, 229-245. [CrossRef]

43. Riba, M.B.; Donovan, K.A.; Andersen, B.; Braun, I.; Breitbart, W.S.; Brewer, B.W.; Buchmann, L.O.; Clark, M.M.; Collins, M.; Corbett, C.; et al. NCCN Clinical Practice Guidelines in Oncology: Distress Management, v3.2019. Natl. Compr. Cancer Network. 2019, 17, 1229-1249. Available online: https://www.nccn.org/professionals/physician_gls/pdf/distress.pdf (accessed on 14 December 2021). [CrossRef] [PubMed]

44. Fagundes, C.; LeRoy, A.; Karuga, M. Behavioral Symptoms after Breast Cancer Treatment: A Biobehavioral Approach. J. Pers. Med. 2015, 5, 280-295. [CrossRef] [PubMed]

45. Liu, Y.Z.; Wang, Y.X.; Jiang, C.L. Inflammation: The Common Pathway of Stress-Related Diseases. Front. Hum. Neurosci. 2017, 11, 316. [CrossRef]

46. Reis, J.C.; Antoni, M.H.; Travado, L. Emotional distress, brain functioning, and biobehavioral processes in cancer patients: A neuroimaging review and future directions. CNS Spectr. 2020, 25, 79-100. [CrossRef]

47. National Comprehensive Cancer Netwerk. Survivorship 2021 (Version 3. 2021). 2021. Available online: https://www.nccn.org/ login?ReturnURL=https:/ / www.nccn.org/professionals/physician_gls/pdf/survivorship.pdf (accessed on 8 September 2021).

48. Thornton, L.M.; Andersen, B.L.; Blakely, W.P. The pain, depression, and fatigue symptom cluster in advanced breast cancer: Covariation with the hypothalamic-pituitary-adrenal axis and the sympathetic nervous system. Health Psychol. 2010, $29,333-337$. [CrossRef]

49. Addison, S.; Shirima, D.; Aboagye-Mensah, E.B.; Dunovan, S.G.; Pascal, E.Y.; Lustberg, M.B.; Arthur, E.K.; Nolan, T.S. Effects of tandem cognitive behavioral therapy and healthy lifestyle interventions on health-related outcomes in cancer survivors: A systematic review. J. Cancer Surviv. 2021, 1-24. [CrossRef]

50. Traeger, L.; Penedo, F.J.; Benedict, C.; Dahn, J.R.; Lechner, S.C.; Schneiderman, N.; Antoni, M.H. Identifying how and for whom cognitive-behavioral stress management improves emotional well-being among recent prostate cancer survivors. Psychooncology 2013, 22, 250-259. [CrossRef]

51. Tang, M.; Liu, X.; Wu, Q.; Shi, Y. The Effects of Cognitive-Behavioral Stress Management for Breast Cancer Patients: A Systematic Review and Meta-analysis of Randomized Controlled Trials. Cancer Nurs. 2020, 43, 222-237. [CrossRef] 
52. Danhauer, S.C.; Addington, E.L.; Cohen, L.; Sohl, S.J.; Van Puymbroeck, M.; Albinati, N.K.; Culos-Reed, S.N. Yoga for symptom management in oncology: A review of the evidence base and future directions for research. Cancer 2019, 125, 1979-1989. [CrossRef]

53. Matchim, Y.; Armer, J.M.; Stewart, B.R. Mindfulness-based stress reduction among breast cancer survivors: A literature review and discussion. Oncol. Nurs. Forum 2011, 38, E61-E71. [CrossRef]

54. Chang, Y.C.; Yeh, T.L.; Chang, Y.M.; Hu, W.Y. Short-term Effects of Randomized Mindfulness-Based Intervention in Female Breast Cancer Survivors: A Systematic Review and Meta-analysis. Cancer. Nurs. 2021, 44, E703-E714. [CrossRef]

55. Roth, T. Insomnia: Definition, prevalence, etiology, and consequences. J. Clin. Sleep Med. 2007, 3, S7-S10. [CrossRef]

56. Savard, J.; Ivers, H.; Villa, J.; Caplette-Gingras, A.; Morin, C.M. Natural course of insomnia comorbid with cancer: An 18-month longitudinal study. J. Clin. Oncol. 2011, 29, 3580-3586. [CrossRef]

57. Johnson, J.A.; Rash, J.A.; Campbell, T.S.; Savard, J.; Gehrman, P.R.; Perlis, M.; Carlson, L.E.; Garland, S.N. A systematic review and meta-analysis of randomized controlled trials of cognitive behavior therapy for insomnia (CBT-I) in cancer survivors. Sleep Med. Rev. 2016, 27, 20-28. [CrossRef]

58. Miller, K.D.; Siegel, R.L.; Lin, C.C.; Mariotto, A.B.; Kramer, J.L.; Rowland, J.H.; Stein, K.D.; Alteri, R.; Jemal, A. Cancer treatment and survivorship statistics, 2016. CA Cancer J. Clin. 2016, 66, 271-289. [CrossRef]

59. Hall, D.L.; Mishel, M.H.; Germino, B.B. Living with cancer-related uncertainty: Associations with fatigue, insomnia, and affect in younger breast cancer survivors. Support. Care Cancer 2014, 22, 2489-2495. [CrossRef]

60. Carpenter, J.S.; Elam, J.L.; Ridner, S.H.; Carney, P.H.; Cherry, G.J.; Cucullu, H.L. Sleep, fatigue, and depressive symptoms in breast cancer survivors and matched healthy women experiencing hot flashes. Oncol. Nurs. Forum 2004, 31, 591-5598. [CrossRef]

61. Savard, J.; Davidson, J.R.; Ivers, H.; Quesnel, C.; Rioux, D.; Dupere, V.; Lasnier, M.; Simard, S.; Morin, C.M. The association between nocturnal hot flashes and sleep in breast cancer survivors. J. Pain Symptom Manag. 2004, 27, 513-522. [CrossRef]

62. Gupta, P.; Sturdee, D.W.; Palin, S.L.; Majumder, K.; Fear, R.; Marshall, T.; Paterson, I. Menopausal symptoms in women treated for breast cancer: The prevalence and severity of symptoms and their perceived effects on quality of life. Climacteric 2006, 9, 49-58. [CrossRef]

63. Desai, K.; Mao, J.J.; Su, I.; Demichele, A.; Li, Q.; Xie, S.X.; Gehrman, P.R. Prevalence and risk factors for insomnia among breast cancer patients on aromatase inhibitors. Support. Care Cancer 2013, 21, 43-51. [CrossRef]

64. Leysen, L.; Lahousse, A.; Nijs, J.; Adriaenssens, N.; Mairesse, O.; Ivakhnov, S.; Bilterys, T.; Van Looveren, E.; Pas, R.; Beckwée, D. Prevalence and risk factors of sleep disturbances in breast cancersurvivors: Systematic review and meta-analyses. Support. Care Cancer 2019, 27, 4401-4433. [CrossRef]

65. Finan, P.H.; Goodin, B.R.; Smith, M.T. The association of sleep and pain: An update and a path forward. J. Pain 2013, 14, 1539-1552. [CrossRef]

66. Haack, M.; Simpson, N.; Sethna, N.; Kaur, S.; Mullington, J. Sleep deficiency and chronic pain: Potential underlying mechanisms and clinical implications. Neuropsychopharmacology 2020, 45, 205-216. [CrossRef]

67. Qaseem, A.; Kansagara, D.; Forciea, M.A.; Cooke, M.; Denberg, T.D. Management of Chronic Insomnia Disorder in Adults: A Clinical Practice Guideline From the American College of Physicians. Ann. Intern. Med. 2016, 165, 125-133. [CrossRef] [PubMed]

68. Perlis, M.L.; Jungquist, C.; Smith, M.T.; Posner, D. Cognitive Behavioral Treatment of Insomnia: A Session-by-Session Guide; Springer Science and Business Media: New York, NY, USA, 2008.

69. Ma, Y.; Hall, D.L.; Ngo, L.H.; Liu, Q.; Bain, P.A.; Yeh, G.Y. Efficacy of cognitive behavioral therapy for insomnia in breast cancer: A meta-analysis. Sleep Med. Rev. 2021, 55, 101376. [CrossRef]

70. Zhou, E.S.; Partridge, A.H.; Syrjala, K.L.; Michaud, A.L.; Recklitis, C.J. Evaluation and treatment of insomnia in adult cancer survivorship programs. J. Cancer Surviv. 2017, 11, 74-79. [CrossRef] [PubMed]

71. Mindell, J.A.; Bartle, A.; Wahab, N.A.; Ahn, Y.; Ramamurthy, M.B.; Huong, H.T.; Kohyama, J.; Ruangdaraganon, N.; Sekartini, R.; Teng, A.; et al. Sleep education in medical school curriculum: A glimpse across countries. Sleep Med. 2011, 12, 928-931. [CrossRef] [PubMed]

72. Thomas, A.; Grandner, M.; Nowakowski, S.; Nesom, G.; Corbitt, C.; Perlis, M.L. Where are the Behavioral Sleep Medicine Providers and Where are They Needed? A Geographic Assessment. Behav. Sleep Med. 2016, 14, 687-698. [CrossRef]

73. Stinson, K.; Tang, N.K.; Harvey, A.G. Barriers to treatment seeking in primary insomnia in the United Kingdom: A cross-sectional perspective. Sleep 2006, 29, 1643-1646. [CrossRef]

74. Matthews, E.E.; Arnedt, J.T.; McCarthy, M.S.; Cuddihy, L.J.; Aloia, M.S. Adherence to cognitive behavioral therapy for insomnia: A systematic review. Sleep Med. Rev. 2013, 17, 453-464. [CrossRef]

75. American Cancer Society. Cancer Treatment E Survivorship Facts \& Figures 2019-2021; American Cancer Society: Atlanta, GA, USA, 2019; Available online: https://www.cancer.org/content/dam/cancer-org/research/cancer-facts-and-statistics/cancertreatment-and-survivorship-facts-and-figures/cancer-treatment-and-survivorship-facts-and-figures-2019-2021.pdf (accessed on 20 September 2021).

76. Zhang, F.F.; Liu, S.; John, E.M.; Must, A.; Demark-Wahnefried, W. Diet quality of cancer survivors and noncancer individuals: Results from a national survey. Cancer 2015, 121, 4212-4221. [CrossRef]

77. Schwedhelm, C.; Boeing, H.; Hoffmann, G.; Aleksandrova, K.; Schwingshackl, L. Effect of diet on mortality and cancer recurrence among cancer survivors: A systematic review and meta-analysis of cohort studies. Nutr. Rev. 2016, 74, 737-748. [CrossRef] 
78. Jochems, S.H.J.; Van Osch, F.H.M.; Bryan, R.T.; Wesselius, A.; van Schooten, F.J.; Cheng, K.K.; Zeegers, M.P. Impact of dietary patterns and the main food groups on mortality and recurrence in cancer survivors: A systematic review of current epidemiological literature. BMJ Open 2018, 8, e014530. [CrossRef] [PubMed]

79. Schwingshackl, L.; Schwedhelm, C.; Galbete, C.; Hoffmann, G. Adherence to Mediterranean Diet and Risk of Cancer: An Updated Systematic Review and Meta-Analysis. Nutrients 2017, 9, 1063. [CrossRef] [PubMed]

80. Yilmaz, S.T.; Elma, Ö.; Deliens, T.; Coppieters, I.; Clarys, P.; Nijs, J.; Malfliet, A. Nutrition/Dietary Supplements and Chronic Pain in Patients with Cancer and Survivors of Cancer: A Systematic Review and Research Agenda. Pain Physician 2021, 24, 335-344 [PubMed]

81. Kim, T.H.; Kang, J.W.; Lee, T.H. Therapeutic options for aromatase inhibitor-associated arthralgia in breast cancer survivors: A systematic review of systematic reviews, evidence mapping, and network meta-analysis. Maturitas 2018, 118, 29-37. [CrossRef]

82. Mohammadi, S.; Sulaiman, S.; Koon, P.B.; Amani, R.; Hosseini, S.M. Association of nutritional status with quality of life in breast cancer survivors. Asian Pac. J. Cancer Prev. 2013, 14, 7749-7755. [CrossRef]

83. Fu, M.R.; Axelrod, D.; Guth, A.; McTernan, M.L.; Qiu, J.M.; Zhou, Z.; Ko, E.; Magny-Normilus, C.; Scagliola, J.; Wang, Y. The Effects of Obesity on Lymphatic Pain and Swelling in Breast Cancer Patients. Biomedicines 2021, 9, 818. [CrossRef]

84. Blazek, K.; Favre, J.; Asay, J.; Erhart-Hledik, J.; Andriacchi, T. Age and obesity alter the relationship between femoral articular cartilage thickness and ambulatory loads in individuals without osteoarthritis. J. Orthop. Res. 2014, 32, 394-402. [CrossRef]

85. Rogers, A.H.; Kauffman, B.Y.; Garey, L.; Asmundson, G.J.; Zvolensky, M.J. Pain-Related Anxiety among Adults with Obesity and Chronic Pain: Relations with Pain, Opioid Misuse, and Mental Health. Behav. Med. 2020, 1-9. [CrossRef]

86. Singh, D.; Park, W.; Hwang, D.; Levy, M.S. Severe obesity effect on low back biomechanical stress of manual load lifting. Work 2015, 51, 337-348. [CrossRef]

87. Fabris de Souza, S.A.; Faintuch, J.; Valezi, A.C.; Sant'Anna, A.F.; Gama-Rodrigues, J.J.; de Batista Fonseca, I.C.; de Melo, R.D. Postural changes in morbidly obese patients. Obes. Surg. 2005, 15, 1013-1016. [CrossRef]

88. Timmins, H.C.; Mizrahi, D.; Li, T.; Kiernan, M.C.; Goldstein, D.; Park, S.B. Metabolic and lifestyle risk factors for chemotherapyinduced peripheral neuropathy in taxane and platinum-treated patients: A systematic review. J. Cancer Surviv. 2021, 1-15. [CrossRef]

89. Parekh, N.; Chandran, U.; Bandera, E.V. Obesity in cancer survival. Annu. Rev. Nutr. 2012, 32, 311-342. [CrossRef]

90. Miller, K.D.; Nogueira, L.; Mariotto, A.B.; Rowland, J.H.; Yabroff, K.R.; Alfano, C.M.; Jemal, A.; Kramer, J.L.; Siegel, R.L. Cancer treatment and survivorship statistics, 2019. CA Cancer J. Clin. 2019, 69, 363-385. [CrossRef]

91. Bracken-Clarke, D.; Kapoor, D.; Baird, A.M.; Buchanan, P.J.; Gately, K.; Cuffe, S.; Finn, S.P. Vaping and lung cancer-A review of current data and recommendations. Lung Cancer 2021, 153, 11-20. [CrossRef]

92. Strick, K. E-cigarettes: Time to realign our approach? Lancet 2019, 394, 1297.

93. Lucchiari, C.; Masiero, M.; Botturi, A.; Pravettoni, G. Helping patients to reduce tobacco consumption in oncology: A narrative review. Springerplus 2016, 5, 1136. [CrossRef]

94. De Moor, J.S.; Elder, K.; Emmons, K.M. Smoking prevention and cessation interventions for cancer survivors. Semin. Oncol. Nurs. 2008, 24, 180-192. [CrossRef] [PubMed]

95. Santa Mina, D.; Brahmbhatt, P.; Lopez, C.; Baima, J.; Gillis, C.; Trachtenberg, L.; Silver, J.K. The Case for Prehabilitation Prior to Breast Cancer Treatment. PMER 2017, 9, S305-S316.

96. Sørensen, L.T.; Hørby, J.; Friis, E.; Pilsgaard, B.; Jørgensen, T. Smoking as a risk factor for wound healing and infection in breast cancer surgery. Eur. J. Surg. Oncol. 2002, 28, 815-820. [CrossRef] [PubMed]

97. Cancer Trends Progress Report National Cancer Institute. Available online: https://www.progressreport.cancer.gov/after/ smoking (accessed on 20 September 2021).

98. Aigner, C.J.; Cinciripini, P.M.; Anderson, K.O.; Baum, G.P.; Gritz, E.R.; Lam, C.Y. The Association of Pain With Smoking and Quit Attempts in an Electronic Diary Study of Cancer Patients Trying to Quit. Nicotine Tob. Res. 2016, 18, 1449-1455. [CrossRef] [PubMed]

99. Ditre, J.W.; Heckman, B.W.; Zale, E.L.; Kosiba, J.D. Acute analgesic effects of nicotine and tobacco in humans: A meta-analysis. Pain 2016, 157, 1373-1381. [CrossRef]

100. Davidson, S.M.; Boldt, R.G.; Louie, A.V. How can we better help cancer patients quit smoking? The London Regional Cancer Program experience with smoking cessation. Curr. Oncol. 2018, 25, 226-230. [CrossRef]

101. Richter, K.P.; Ellerbeck, E.F. It's time to change the default for tobacco treatment. Addiction 2015, 110, 381-386. [CrossRef] [PubMed]

102. Bagnardi, V.; Rota, M.; Botteri, E.; Tramacere, I.; Islami, F.; Fedirko, V.; Scotti, L.; Jenab, M.; Turati, F.; Pasquali, E.; et al. Alcohol consumption and site-specific cancer risk: A comprehensive dose-response meta-analysis. Br. J. Cancer 2015, 112, 580-593. [CrossRef] [PubMed]

103. Cao, Y.; Willett, W.C.; Rimm, E.B.; Stampfer, M.J.; Giovannucci, E.L. Light to moderate intake of alcohol, drinking patterns, and risk of cancer: Results from two prospective US cohort studies. BMJ 2015, 351, h4238. [CrossRef] [PubMed]

104. Bagnardi, V.; Rota, M.; Botteri, E.; Tramacere, I.; Islami, F.; Fedirko, V.; Scotti, L.; Jenab, M.; Turati, F.; Pasquali, E.; et al. Light alcohol drinking and cancer: A meta-analysis. Ann. Oncol. 2013, 24, 301-308. [CrossRef] [PubMed]

105. Myung, S.K. Erroneous conclusions about the association between light alcohol drinking and the risk of cancer: Comments on Bagnardi et al.'s meta-analysis. Ann. Oncol. 2016, 27, 2138. [CrossRef] 
106. Xia, E.Q.; Deng, G.F.; Guo, Y.J.; Li, H.B. Biological activities of polyphenols from grapes. Int. J. Mol. Sci. 2010, 11, 622-646. [CrossRef]

107. Ali, A.M.; Schmidt, M.K.; Bolla, M.K.; Wang, Q.; Gago-Dominguez, M.; Castelao, J.E.; Carracedo, A.; Garzón, V.M.; Bojesen, S.E.; Nordestgaard, B.G.; et al. Alcohol consumption and survival after a breast cancer diagnosis: A literature-based meta-analysis and collaborative analysis of data for 29,239 cases. Cancer Epidemiol. Biomark. Prev. 2014, 23, 934-945. [CrossRef]

108. Watts, E.L.; Appleby, P.N.; Perez-Cornago, A.; Bueno-de-Mesquita, H.B.; Chan, J.M.; Chen, C.; Cohn, B.A.; Cook, M.B.; Flicker, L.; Freedman, N.D.; et al. Low Free Testosterone and Prostate Cancer Risk: A Collaborative Analysis of 20 Prospective Studies. Eur. Urol. 2018, 74, 585-594. [CrossRef]

109. Sanford, N.N.; Sher, D.J.; Xu, X.; Ahn, C.; D'Amico, A.V.; Aizer, A.A.; Mahal, B.A. Alcohol use among patients with cancer and survivors in the United States 2000-2017. J. Natl. Compr. Cancer Netw. 2020, 18, 69-79. [CrossRef] [PubMed]

110. Hashibe, M.; Brennan, P.; Chuang, S.C.; Boccia, S.; Castellsague, X.; Chen, C.; Curado, M.P.; Dal Maso, L.; Daudt, A.W.; Fabianova, E.; et al. Interaction between tobacco and alcohol use and the risk of head and neck cancer: Pooled analysis in the International Head and Neck Cancer Epidemiology Consortium. Cancer Epidemiol. Biomark. Prev. 2009, 18, 541-550. [CrossRef] [PubMed]

111. Thompson, T.; Oram, C.; Correll, C.U.; Tsermentseli, S.; Stubbs, B. Analgesic effects of alcohol: A systematic review and meta-analysis of controlled experimental studies in healthy participants. J. Pain 2017, 18, 499-510. [CrossRef] [PubMed]

112. Zale, E.L.; Maisto, S.A.; Ditre, J.W. Interrelations between pain and alcohol: An integrative review. Clin. Psychol. Rev. 2015, 37, 57-71. [CrossRef] [PubMed]

113. Boissoneault, J.; Lewis, B.; Nixon, S.J. Characterizing chronic pain and alcohol use trajectory among treatment-seeking alcoholics. Alcohol 2019, 75, 47-54. [CrossRef] [PubMed]

114. Maleki, N.; Oscar-Berman, M. Chronic Pain in Relation to Depressive Disorders and Alcohol Abuse. Brain Sci. 2020, 10, 826. [CrossRef]

115. Nieto, S.J.; Green, R.; Grodin, E.N.; Cahill, C.M.; Ray, L.A. Pain catastrophizing predicts alcohol craving in heavy drinkers independent of pain intensity. Drug Alcohol Depend. 2021, 218, 108368. [CrossRef]

116. Rock, C.L.; Doyle, C.; Demark-Wahnefried, W.; Meyerhardt, J.; Courneya, K.S.; Schwartz, A.L.; Bandera, E.V.; Hamilton, K.K.; Grant, B.; McCullough, M.; et al. Nutrition and physical activity guidelines for cancer survivors. CA Cancer J. Clin. 2012, 62, 243-274. [CrossRef]

117. Friedenreich, C.M.; Stone, C.R.; Cheung, W.Y.; Hayes, S.C. Physical Activity and Mortality in Cancer Survivors: A Systematic Review and Meta-Analysis. JNCI Cancer Spectr. 2020, 4, pkz080. [CrossRef]

118. Turner, R.R.; Steed, L.; Quirk, H.; Greasley, R.U.; Saxton, J.M.; Taylor, S.J.; Rosario, D.J.; Thaha, M.A.; Bourke, L. Interventions for promoting habitual exercise in people living with and beyond cancer. Cochrane Database Syst. Rev. 2018, 9. [CrossRef]

119. Garcia, D.O.; Thomson, C.A. Physical activity and cancer survivorship. Nutr. Clin. Pract. 2014, 29, 768-779. [CrossRef]

120. Wolin, K.Y.; Schwartz, A.L.; Matthews, C.E.; Courneya, K.S.; Schmitz, K.H. Implementing the exercise guidelines for cancer survivors. J. Support. Oncol. 2012, 10, 171-177. [CrossRef]

121. Runowicz, C.D.; Leach, C.R.; Henry, N.L.; Henry, K.S.; Mackey, H.T.; Cowens-Alvarado, R.L.; Cannady, R.S.; Pratt-Chapman, M.L.; Edge, S.B.; Jacobs, L.A.; et al. American Cancer Society/American Society of Clinical Oncology Breast Cancer Survivorship Care Guideline. J. Clin. Oncol. 2016, 34, 611-635. [CrossRef]

122. Lu, G.; Zheng, J.; Zhang, L. The effect of exercise on aromatase inhibitor-induced musculoskeletal symptoms in breast cancer survivors: A systematic review and meta-analysis. Support. Care Cancer 2020, 28, 1587-1596. [CrossRef] [PubMed]

123. Boing, L.; Vieira, M.C.S.; Moratelli, J.; Bergmann, A.; Guimarães, A.C.A. Effects of exercise on physical outcomes of breast cancer survivors receiving hormone therapy-A systematic review and meta-analysis. Maturitas 2020, 141, 71-81. [CrossRef]

124. Ballard-Barbash, R.; Friedenreich, C.M.; Courneya, K.S.; Siddiqi, S.M.; McTiernan, A.; Alfano, C.M. Physical activity, biomarkers, and disease outcomes in cancer survivors: A systematic review. J. Natl. Cancer Inst. 2012, 104, 815-840. [CrossRef] [PubMed]

125. Hasenoehrl, T.; Palma, S.; Ramazanova, D.; Kölbl, H.; Dorner, T.E.; Keilani, M.; Crevenna, R. Resistance exercise and breast cancer-related lymphedema-a systematic review update and meta-analysis. Support Care Cancer 2020, 28, 3593-3603. [CrossRef] [PubMed]

126. Geneen, L.J.; Moore, R.A.; Clarke, C.; Martin, D.; Colvin, L.A.; Smith, B.H. Physical activity and exercise for chronic pain in adults: An overview of Cochrane Reviews. Cochrane Database Syst. Rev. 2017, 1, Cd011279. [PubMed]

127. Lavín-Pérez, A.M.; Collado-Mateo, D.; Mayo, X.; Liguori, G.; Humphreys, L.; Copeland, R.J.; Jiménez, A. Effects of high-intensity training on the quality of life of cancer patients and survivors: A systematic review with meta-analysis. Sci. Rep. 2021, 11, 15089. [CrossRef]

128. Ijsbrandy, C.; Ottevanger, P.B.; Gerritsen, W.R.; van Harten, W.H.; Hermens, R. Determinants of adherence to physical cancer rehabilitation guidelines among cancer patients and cancer centers: A cross-sectional observational study. J. Cancer Surviv. 2021, 15, 163-177. [CrossRef]

129. Kampshoff, C.S.; Jansen, F.; van Mechelen, W.; May, A.M.; Brug, J.; Chinapaw, M.J.; Buffart, L.M. Determinants of exercise adherence and maintenance among cancer survivors: A systematic review. Int. J. Behav. Nutr. Phys. Act. 2014, 11, 80. [CrossRef]

130. Ormel, H.L.; van der Schoot, G.G.F.; Sluiter, W.J.; Jalving, M.; Gietema, J.A.; Walenkamp, A.M.E. Predictors of adherence to exercise interventions during and after cancer treatment: A systematic review. Psychooncology 2018, 27, 713-724. [CrossRef]

131. Spencer, J.C.; Wheeler, S.B. A systematic review of Motivational Interviewing interventions in cancer patients and survivors. Patient Educ. Couns. 2016, 99, 1099-1105. [CrossRef] 
132. Veenhof, C.; Köke, A.J.; Dekker, J.; Oostendorp, R.A.; Bijlsma, J.W.; van Tulder, M.W.; van den Ende, C.H. Effectiveness of behavioral graded activity in patients with osteoarthritis of the hip and/or knee: A randomized clinical trial. Arthritis Rheum. 2006, 55, 925-934. [CrossRef]

133. Cillessen, L.; Johannsen, M.; Speckens, A.E.M.; Zachariae, R. Mindfulness-based interventions for psychological and physical health outcomes in cancer patients and survivors: A systematic review and meta-analysis of randomized controlled trials. Psychooncology 2019, 28, 2257-2269. [CrossRef]

134. Duan, L.; Xu, Y.; Li, M. Effects of Mind-Body Exercise in Cancer Survivors: A Systematic Review and Meta-Analysis. Evid. Based Complement. Altern. Med. 2020, 2020, 7607161. [CrossRef]

135. Mendoza, M.E.; Capafons, A.; Gralow, J.R.; Syrjala, K.L.; Suárez-Rodríguez, J.M.; Fann, J.R.; Jensen, M.P. Randomized controlled trial of the Valencia model of waking hypnosis plus CBT for pain, fatigue, and sleep management in patients with cancer and cancer survivors. Psychooncology 2017, 26, 1832-1838. [CrossRef]

136. The Joanna Briggs Institute Levels of Evidence and Grades of RecommendationWorking Party Joanna Briggs Institute Levels of Evidence and Grades of Recommendation. 2014. Available online: https://jbi.global/sites/default/files/2019-05/JBI-Levels-ofevidence_2014_0.pdf (accessed on 22 November 2021).

137. Hernandez Silva, E.; Lawler, S.; Langbecker, D. The effectiveness of mHealth for self-management in improving pain, psychological distress, fatigue, and sleep in cancer survivors: A systematic review. J. Cancer Surviv. 2019, 13, 97-107. [CrossRef]

138. Mullan, F. Seasons of survival: Reflections of a physician with cancer. N. Engl. J. Med. 1985, 313, 270-273. [CrossRef] [PubMed]

139. Paxton, R.J.; Jones, L.A.; Chang, S.; Hernandez, M.; Hajek, R.A.; Flatt, S.W.; Natarajan, L.; Pierce, J.P. Was race a factor in the outcomes of the Women's Health Eating and Living Study? Cancer 2011, 117, 3805-3813. [CrossRef] [PubMed]

140. Blanchard, C.M.; Courneya, K.S.; Stein, K. Cancer survivors' adherence to lifestyle behavior recommendations and associations with health-related quality of life: Results from the American Cancer Society's SCS-II. J. Clin. Oncol. 2008, 26, 2198-2204. [CrossRef]

141. Bower, P.; Gilbody, S. Stepped care in psychological therapies: Access, effectiveness and efficiency. Narrative literature review. Br. J. Psychiatry 2005, 186, 11-17. [CrossRef]

142. Zhou, E.S.; Michaud, A.L.; Recklitis, C.J. Developing efficient and effective behavioral treatment for insomnia in cancer survivors: Results of a stepped care trial. Cancer 2020, 126, 165-173. [CrossRef]

143. Lynch, F.A.; Katona, L.; Jefford, M.; Smith, A.B.; Shaw, J.; Dhillon, H.M.; Ellen, S.; Phipps-Nelson, J.; Lai-Kwon, J.; Milne, D.; et al. Feasibility and Acceptability of Fear-Less: A Stepped-Care Program to Manage Fear of Cancer Recurrence in People with Metastatic Melanoma. J. Clin. Med. 2020, 9, 2969. [CrossRef] [PubMed]

144. Roberts, A.L.; Fisher, A.; Smith, L.; Heinrich, M.; Potts, H.W.W. Digital health behaviour change interventions targeting physical activity and diet in cancer survivors: A systematic review and meta-analysis. J. Cancer Surviv. 2017, 11, 704-719. [CrossRef] [PubMed]

145. Yang, W.; Williams, J.H.; Hogan, P.F.; Bruinooge, S.S.; Rodriguez, G.I.; Kosty, M.P.; Bajorin, D.F.; Hanley, A.; Muchow, A.; McMillan, N.; et al. Projected supply of and demand for oncologists and radiation oncologists through 2025: An aging, better-insured population will result in shortage. J. Oncol. Pract. 2014, 10, 39-45. [CrossRef] [PubMed]

146. Nijs, J.; Wijma, A.J.; Leysen, L.; Pas, R.; Willaert, W.; Hoelen, W.; Ickmans, K.; Wilgen, C.P.V. Explaining pain following cancer: A practical guide for clinicians. Braz. J. Phys. Ther. 2019, 23, 367-377. [CrossRef]

147. Lexmond, W.; Jäger, K. Psychomteric Properties of the Dutch Version of the Revised Neurophysiology of Pain Questionnaire; Vrije Universiteit Brussel: Brussels, Belgium, 2019; p. 36.

148. Bennett, M.I.; Bagnall, A.M.; Closs, S.J. How effective are patient-based educational interventions in the management of cancer pain? Systematic review and meta-analysis. Pain 2009, 143, 192-199. [CrossRef]

149. Nijs, J.; Roose, E.; Lahousse, A.; Mostaqim, K.; Reynebeau, I.; De Couck, M.; Beckwee, D.; Huysmans, E.; Bults, R.; van Wilgen, P.; et al. Pain and Opioid Use in Cancer Survivors: A Practical Guide to Account for Perceived Injustice. Pain Physician 2021, 24, 309-317.

150. Levit, L.A.; Balogh, E.; Nass, S.J.; Ganz, P. Delivering High-Quality Cancer Care: Charting a New Course for a System in Crisis; National Academies Press: Washington, DC, USA, 2013.

151. Bluethmann, S.M.; Mariotto, A.B.; Rowland, J.H. Anticipating the "Silver Tsunami": Prevalence Trajectories and Comorbidity Burden among Older Cancer Survivors in the United States. Cancer Epidemiol. Biomark. Prev. 2016, 25, 1029-1036. [CrossRef] 